\title{
Effect of NPKS and Zn Fertilization on, Growth, Yield and Quality of Baby Corn-A Review
}

\author{
Rakesh Kumar ${ }^{1}$, Narendra Kumawat ${ }^{2} *$, Sudhir Kumar ${ }^{4}$, \\ Amitesh Kumar Singh ${ }^{5}$ and J.S. Bohra ${ }^{3}$
}

\author{
${ }^{1}$ ICAR-Research Complex for Eastern Region, Patna-797 106, Bihar, India \\ ${ }^{2}$ AICRP on Maize-Zonal Agricultural Research Station, Jhabua-457661, MP, India \\ ${ }^{3}$ Department of Agronomy, I.A.S., BHU, Varansi-221 005, UP, India \\ ${ }^{4}$ ICAR-Research Complex for NEH Region, Manipur Centre Lamphelpat, Imphal-795004, India \\ ${ }^{5}$ Department of Agronomy, IAS, RGSC (BHU), Barkachha, Mirzapur, (U.P.), India \\ *Corresponding author
}

\section{A B S T R A C T}

\section{Keywords}

Baby corn,

Nitrogen,

Phosphorus,

Potassium, Quality, Sulphur.

Article Info

Accepted:

20 February 2017

Available Online:

10 March 2017

\begin{abstract}
Nutrient management is one of the most crucial factors in scientific crop productions. The knowledge regarding use of optimum dose of crop nutrition is of prime concern in modern agriculture. The findings of this paper will be helpful in understanding the views of active investigators, theoreticians and practitioners on growth, yield, quality, nutrient uptake, soil health and economics of baby corn. Maize is an exhaustive crop and for gaining higher productivity, it requires very high quantities of nitrogen during the period of efficient utilization. Application of $120 \mathrm{~kg} \mathrm{~N} \mathrm{ha}^{-1}$ reduced the days to corn initiation but prolonged the harvesting period over $80 \mathrm{~kg} \mathrm{~N} \mathrm{ha}^{-1}$. Application of $30 \mathrm{~kg} \mathrm{P} \mathrm{ha}^{-1}$ is reported to be beneficial and economical for baby corn production under the normal management. Potassium regulates the osmotic potential of cells and imparts resistance to biotic and abiotic stresses. Application of $\mathrm{S}$ and $\mathrm{Zn}$ has resulted in significant improvement for crude protein, $\mathrm{Ca}$, ash in baby corn. Application of $125 \% \mathrm{RDF}\left(187.5-93.7-75 \mathrm{~kg} \mathrm{ha}^{-1}\right)$ and $50 \mathrm{~kg}$ $\mathrm{S} \mathrm{ha}^{-1}$ along with $10 \mathrm{~kg} \mathrm{Zn} \mathrm{ha}{ }^{-1}$ has great impact on corn production in maximizing corn yield, fodder yield, nutrient content and monetary returns to the growers.
\end{abstract}

\section{Introduction}

Maize (Zea mays L.) ranks $3^{\text {rd }}$ as a food-grain crop after wheat and rice and it is not only as a cereal but also as vegetable and fodder crop. Maize cobs are used as a vegetable is known as baby corn. Baby corn having unfertilized young cobs harvested 2 or 3 days after silk emergence. Globally, as an immature vegetable, baby corn has attracted an increasing number of peoples' preference due to the enhancement of living standards and shift in dietary habit from non-vegetarian to vegetarian; however, production areas are still confined to a few countries, including Thailand, Indonesia, India, and Brazil. The greatest production of baby corn is in Thailand (Wang et al., 2009). Das et al., (2008) found that $100 \mathrm{~g}$ of baby corn contained $89.1 \%$ moisture, $0.2 \mathrm{~g}$ fat, $1.9 \mathrm{~g}$ protein, $8.2 \mathrm{mg}$ carbohydrate, $0.06 \mathrm{~g}$ ash, 28.0 $\mathrm{mg}$ calcium, $86.0 \mathrm{mg}$ phosphorus, and 11.0 
mg of ascorbic acid (Thavaprakaash et al., 2005). Baby corn production being a new introduction to Indian agriculture, very limited research literature is available on this specific aspect. However, comprehensive efforts have been made to review the research work done in this regard along with maize/corn by the eminent scientists in the country and abroad and the available experimental findings have been incorporated in this chapter. Brief resume of research work relevant to the investigation entitled "Effect of NPKS and Zn application on growth, yield and quality of baby corn (Zea mays L.)" has been reviewed under the following objectives:

- Effect of fertility levels on growth parameters, yield attributes, yield, quality, nutrient contents, nutrient uptake, soil health and economics of baby corn

- Effect of sulphur levels on growth parameters, yield attributes and yield, quality, nutrient contents, nutrient uptake, soil health and economics of baby corn

- Effect of zinc levels on growth parameters, yield attributes, yield, quality, nutrient contents, nutrient uptake, soil health and economics of baby corn.

Growth and development of the crop plants are directly related to their genetic constitution, though environmental factors and cultural practices do influence it through their direct and indirect impact on different metabolic process of the plants. Thus, agricultural production being consequence of an integrated interaction effect of soil-waterfertilizer-climate continuum, which requires a wiseful and scientific management of this complex system, this is quite crucial for enhancing crop productivity on sustainable basis. Among the various inputs, mineral nutrition of plants is the key input to making maximum contribution of crop productivity because nearly $55 \%$ of increase in food grain production during last two decades has come through increasing levels of fertilizer application. However, total annual removal of nutrient by crop and cropping system being much higher than amount added through fertilizers has resulted in negative nutrient balance in the soil. Therefore, prompt effort is must, not only to increase and stabilize crop production but also to enhance the nutrient use efficiency, which shows great influence on crop production. The productivity of baby corn entirely depends on extent of successful completion of crop growth for exploiting their full genetic potential and properly integrated with environmental conditions in which it is grown. However, role of balanced and adequate nutrition is recognized as one of the important factors in realizing the maximum yield of baby corn. Role of nutrients for effective progression of plant ontogeny and crop yield as well as in quality improvement of crop has been well recognized. Besides, the major primary nutrients i.e. $\mathrm{N}, \mathrm{P}$ and $\mathrm{K}$, secondary nutrients like sulphur and micronutrients i.e. zinc has been recognized as essential inputs for sustained the baby corn productivity and enhancement in its quality.

Nitrogen $(\mathrm{N})$ is a vital plant nutrient and a major determining factor required for maize production (Shanti et al., 1997).Nitrogen is a component of protein and nucleic acids and when $\mathrm{N}$ is suboptimal, growth is reduced. Its availability in sufficient quantity throughout the growing season is essential for optimum maize growth (Haque et al., 2001).Nitrogen as a major constituent of cell plays a vital role in cell division and elongation by virtue of being an essential part of diverse type of metabolically active compound like amino acids, proteins, nucleic acids, prophyrins, flavins, purines and pyramidine nucleotides, enzymes, co-enzymes and alkaloids. Therefore, it is a vitally associated with the activity of every living cell. Thus, greater availability of nitrogen at higher fertilizer doses might have improved protein synthesis 
and photosynthesis leading thereby to rapid cell division and enlargement, which ultimately resulted in to vigorous plant growth. Phosphorus is the second essential nutrient required to higher yield of maize. Consequently, lack of phosphorus is as important as the lack of nitrogen limiting maize performance (Gul et al., 2015).Phosphorus, as a constituent of ADP and ATP, plays a key role in energy transformation. It also helps in assimilation of photosynthates into other metabolites and hence acts as an activity zone for $\mathrm{CO}_{2}$ assimilation. It is important for seed and fruit formation and crop maturation. Phosphorus hastens ripening of fruits thus counteracting the effect of excess nitrogen application to the soil. Moreover, as an integral part of chromosomes, it stimulates cell division and is necessary for meristematic growth. Thus, adequate supply of phosphorus helps in rapid growth of plant. Likewise, potassium is an essential nutrient and is also the most abundant cation in plants. It plays essential roles in enzyme activation, protein synthesis, photosynthesis, osmoregulation, stomatal movement, energy transfer, phloem transport, cation-anion balance, and stress resistance (Gul et al., 2015). As such adequate and balanced supply of N, P and $\mathrm{K}$ at $125 \% \mathrm{RDF}$ to baby corn crop might have favoured greater availability of these nutrients that ultimately resulted in to enhanced growth of the plants (Kumar 2013; Kumar and Bohra 2014; Kumar et al., 2015a,b,c).

\section{Effect of nitrogen}

Nitrogen is one of the most important nutrients in maize grown for baby corn production. Being structural components of amino acids, protein molecules, enzymes, alkaloids, nucleotides, chlorophyll and other constituents, it plays a vital role in growth and development of plants. The response of nitrogen to baby corn has been presented in this section.

\section{Growth characters}

Thakur et al., (1997) carried out a field study during rainy season on sandy loam soil at Bajaura (Himanchal Pradesh) to assess the effect of nitrogen levels on baby corn var. "Early composite" and noticed that application of $150-200 \mathrm{~kg} \mathrm{~N}^{-1}$ registered significantly higher plant height, functional leaves and dry matter accumulation plant $^{-1}$ over nitrogen application rates below $100 \mathrm{~kg}$ $\mathrm{N} \mathrm{ha}^{-1}$. Majumdar et al., (2002) noticed that application $100 \mathrm{~kg} \mathrm{~N} \mathrm{ha}^{-1}$ recorded the highest growth attributes in maize. While working on fodder maize at Faisalabad (Pakistan), Ayub et al., (2003) noticed that application of 120 $\mathrm{kg} \mathrm{N}$ ha $^{-1}$ registered the tallest plant, leaves plant $^{-1}$ and stem diameter of maize over the control and $80 \mathrm{~kg} \mathrm{~N} \mathrm{ha}^{-1}$. In Turkey working on maize, Adiloglu and Saglam (2005) determined effect of nitrogen levels on maize and noticed significantly higher dry matter content with increasing levels of nitrogen up to $100 \mathrm{~kg} \mathrm{~N} \mathrm{ha}{ }^{-1}$. Keskin et al., (2005) working on forage maize noticed marked increase in plant height with increasing rates of nitrogen application up to $200 \mathrm{~kg} \mathrm{ha}^{-1}$. Application of $150 \mathrm{~kg} \mathrm{~N} \mathrm{ha}{ }^{-1}$ significantly increased plant height, number of green leaf, leaf area index and dry matter plant ${ }^{-1}$ but it remained at par with $100 \mathrm{~kg} \mathrm{~N} \mathrm{ha}^{-1}$ (Maurya et al., 2005). Harikrishna et al., (2005) at Dharwad noticed that application of $200 \%$ RDN recorded significantly taller plant leaf area index and dry matter yield over $100 \%$ RDN (150 kg N ha-1) but remained on par with $150 \%$ RDN. A field experiment at Bhubaneswar was conducted to assess the effect of nitrogen levels on growth of baby corn var. Navjot and noted significantly taller plant, dry matter and leaf area index with 120 $\mathrm{kg} \mathrm{N} \mathrm{ha}{ }^{-1}$ over 40 and $80 \mathrm{~kg} \mathrm{~N} h a^{-1}$ (Bindhani et al., 2005). However, Adiloglu and Saglam (2005) noticed that dry matter production of 
maize increased significantly with increasing levels of nitrogen up to $100 \mathrm{~kg} \mathrm{~N} \mathrm{ha}{ }^{-1}$. At Pune, Choudhary et al., (2006) reported that application of $120 \mathrm{~kg} \mathrm{~N} \mathrm{ha}^{-1}$ to maize cv. DCH-103 significantly increased leaf area and dry matter production over 40 and $80 \mathrm{~kg} \mathrm{~N}$ ha 1. Hani et al., (2006) working on forage maize in Sudan noticed that plant height, stem diameter and dry matter yield were improved significantly with application of $80 \mathrm{~kg} \mathrm{~N} \mathrm{ha}^{-1}$ over control but it remained at par with $40 \mathrm{~kg}$ $\mathrm{N} \mathrm{ha}^{-1}$. They also observed that application of $80 \mathrm{~kg} \mathrm{~N} \mathrm{ha}^{-1}$ gave higher LAI over control and $40 \mathrm{~kg} \mathrm{~N} \mathrm{ha}^{-1}$.

At Peshawar (Pakistan), Bakht et al., (2006) studied response of maize to levels of nitrogen and revealed that significantly taller plants, leaves plant ${ }^{-1}$ and more days to $50 \%$ tasseling and silking were noticed with application of $200 \mathrm{~kg} \mathrm{~N}^{-1}$ over $160,120,80$ $\mathrm{kg} \mathrm{N} \mathrm{ha}{ }^{-1}$ and control. Panwar and Munda (2006) conducted a field experiment at Umiam (Meghalaya) during rainy season of 2001 and 2002 to study the response of baby corn cv. Vijay composite to nitrogen doses and found that application of $120 \mathrm{~kg} \mathrm{~N} \mathrm{ha}^{-1}$ reduced the days to baby corn initiation but prolonged harvesting period over $80 \mathrm{~kg} \mathrm{~N}$ ha 1. In China, Xie et al., (2006) working at Habei Province conducting experiment on summer maize with three nitrogen levels $(0$, 90 and $180 \mathrm{~kg} \mathrm{~N} \mathrm{ha}^{-1}$ ) summarized that leaf area index and chlorophyll content increased with increasing rates of nitrogen application up to $180 \mathrm{~kg} \mathrm{~N} \mathrm{ha}^{-1}$. Similarly, enhancement in plant height, LAI and dry matter production in maize were recorded with increasing levels of nitrogen application up to $180 \mathrm{~kg} \mathrm{~N} \mathrm{ha}^{-1}$ (Ram et al., 2006). In another study at Peshawar (Pakistan), Jan et al., (2007) noticed that hybrid maize responded positively to nitrogen application for plant height with increasing levels from 180-300 kg $\mathrm{N} \mathrm{ha}^{-1}$. In Egypt, Siam et al., (2008) studied the effect $\mathrm{N}$ fertilization on maize and reported that nitrogen applied at $140 \mathrm{~kg} \mathrm{~N} \mathrm{ha}^{-1}$ significantly increased plant height and dry weight of leaves over $80 \mathrm{~kg} \mathrm{~N} \mathrm{ha}^{-1}$. Kunjir et al., (2009) tested the performance of sweet corn cv. Sumadhur under the influence of different nitrogen levels (0, 75,150 and 225 $\mathrm{kg} \mathrm{N} \mathrm{ha}{ }^{-1}$ ) and noticed that plant height, number of leaf and dry matter increased significantly with increase in nitrogen levels up to $150 \mathrm{~kg} \mathrm{~N} \mathrm{ha}{ }^{-1}$ but beyond this differences remained statistically on par. At New Delhi, Kumar (2009) studying the response of popcorn to different levels of nitrogen application $(0,40,80$ and $120 \mathrm{~kg} \mathrm{~N}$ $\mathrm{ha}^{-1}$ ) reported that taller plants and higher dry weight plant $^{-1}$ were obtained with each successive increase in nitrogen levels from 0$120 \mathrm{~kg} \mathrm{~N} \mathrm{ha}^{-1}$. Whereas in Iran, Sharifi and Taghizadeh (2009) conducting a field experiment on maize noticed that the significantly taller plant with increasing rates of nitrogen application up to $200 \mathrm{~kg} \mathrm{~N} \mathrm{ha}^{-1}$.

In Nigeria, Effa et al.,(2011) evaluated the response of popcorn var. Ashland to graded levels of nitrogen $\left(0,40,80\right.$ and $\left.120 \mathrm{~kg} \mathrm{~N} \mathrm{ha}^{-1}\right)$ and noticed that plant height, LAI and total dry matter increased with each increment of nitrogen level up to $120 \mathrm{~kg} \mathrm{ha}^{-1}$. However, increasing nitrogen levels from $0-120 \mathrm{~kg} \mathrm{~N}$ $\mathrm{ha}^{-1}$ decreased number of days to $50 \%$ tasseling. Mehta et al., (2011) at Ludhiana revealed application of nitrogen up to $275 \mathrm{~kg}$ $\mathrm{N} \mathrm{ha}^{-1}$ significantly increased plant height, leaf area, dry matter, crop growth rate and relative growth rate over control, 175, 200 and $225 \mathrm{~kg}$ $\mathrm{N} \mathrm{ha}^{-1}$ but remained at par with $250 \mathrm{~kg} \mathrm{~N} \mathrm{ha}^{-1}$. Mahdi et al., (2012) at Shalimar (JK) studied the effect of different nitrogen levels viz. 60, 90 and $120 \mathrm{~kg} \mathrm{~N}^{-1}$ on growth components of fodder maize cv. J-1006 reported that plant height and leaf area index significantly increased up to $120 \mathrm{~kg} \mathrm{~N}^{-1}$. Similarly, Jeet et al., (2012) at Varanasi recorded significantly taller plant; wider stem girth, higher number of green leaf, dry weight, crop 
growth rate and leaf area index with increasing levels of nitrogen application up to $150 \mathrm{~kg} \mathrm{~N} \mathrm{ha}{ }^{-1}$. While, Singh et al., (2012) working on sweet corn cv. Madhuri at Wadura (JK) noticed that each successive increase in nitrogen levels from $0-120 \mathrm{~kg} \mathrm{~N}$ $\mathrm{ha}^{-1}$ significantly increased plant height and dry matter but the differences between 120 and $150 \mathrm{~kg} \mathrm{~N} \mathrm{ha}^{-1}$ remained on par. Studying the response of maize cv. Ganga Safed to different levels of nitrogen $(0,50,100$ and 150 $\mathrm{kg} \mathrm{N} \mathrm{ha}{ }^{-1}$ ) at Hamirpur (U.P), Verma et al., (2012) reported that plant height, total dry matter, leaf area index, number of days to silking and maturity were enhanced significantly with increasing nitrogen levels up to $150 \mathrm{~kg} \mathrm{~N} \mathrm{ha}{ }^{-1}$. Neupane et al., (2011a,b,c) observed that application of $75 \%$ $\mathrm{N}$ through urea+ $25 \% \mathrm{~N}$ through FYM were found the best source of nitrogen and emerged as superior in relation to yield attributes viz. cobs plant ${ }^{-1}$; cob length and cob girth and finally resulted in higher yield of corn for commercial cultivation of baby corn for prekharif season. Similarly, working on maize Raskar et al., (2012) reported that increasing level of nitrogen significantly increased the plant height up to $160 \mathrm{~kg} \mathrm{ha}^{-1}$ but it was at par with $120 \mathrm{~kg} \mathrm{ha}^{-1}$. Jena et al., (2015) working at Rajendranagar, Hyderabad, observed that application of $240 \mathrm{~kg} \mathrm{~N}^{-1}$ gave taller plants and LAI of quality protein maize over the 0 , 120 and $180 \mathrm{~kg} \mathrm{~N} \mathrm{ha}^{-1}$.

\section{Yield attributes and yields}

Working at Faisalabad (Pakistan), Sarwar (1993) studied effect of nitrogen application on maize and noticed significantly higher grain yield with application of increasing levels of nitrogen up to $200 \mathrm{~kg} \mathrm{~N} \mathrm{ha}^{-1}$. Sharma and Thakur (1995) conducted a field experiment during rainy season on sandy loam soil at Bajaura (Himanchal Pradesh) to evaluate the response of baby corn cv. Early composite to nitrogen application and noticed that baby corn yield increased significantly with increasing rates of nitrogen application up to $90 \mathrm{~kg} \mathrm{ha}^{-1}$. However, according to Thakur et al., (1997), yield of baby corn increased significantly with increasing levels of nitrogen application up to $150 \mathrm{~kg} \mathrm{~N} \mathrm{ha}^{-1}$ but baby cob weight with husk and green fodder yield showed significant increase up to $200 \mathrm{~kg} \mathrm{~N} \mathrm{ha}^{-1}$. Whereas, significantly lower barrenness $(\%)$ was noticed with application of increasing levels of nitrogen up to $200 \mathrm{~kg}$ $\mathrm{N} \mathrm{ha}{ }^{-1}$ as compared to $150 \mathrm{~kg} \mathrm{~N} \mathrm{ha}^{-1}$ and lower doses and it was noted significantly higher under control. At Bajaura, working on baby corn, Thakur and Sharma (1999) noticed that increasing levels of nitrogen application up to $150 \mathrm{~kg} \mathrm{~N}^{-1}$ recorded significantly higher yield components i.e. cobs plant ${ }^{-1}$ and cob length but remained at par with $200 \mathrm{~kg} \mathrm{~N}$ $\mathrm{ha}^{-1}$. However, baby corn: husk ratio and barrenness $(\%)$ decreased with application of increasing rate of $\mathrm{N}$ from $100-200 \mathrm{~kg} \mathrm{~N}^{-1}$. Further, they noted that baby corn yield increased progressively with application of increasing rates of $\mathrm{N}$ from $100-200 \mathrm{~kg} \mathrm{~N} \mathrm{ha}^{-1}$. At Coimbatore, while evaluating the effect of different levels of nitrogen on yield of baby corn, Rajendran and Singh (1999) reported that increasing levels of nitrogen application up to $180 \mathrm{~kg} \mathrm{~N} \mathrm{ha}^{-1}$ produced significantly higher cob and corn yield but it did not differ significantly with $150 \mathrm{~kg} \mathrm{~N} \mathrm{ha}{ }^{-1}$. Similarly, Sahoo and Panda (1999) working at Joshipur (Odissa) noticed that corn yield increased significantly with application of increasing levels of nitrogen up to $160 \mathrm{~kg} \mathrm{~N} \mathrm{ha}^{-1}$.

Pandey et al., (2000) working on baby corn hybrid "VL Makka-42" at Almora, noticed that application of increasing levels of nitrogen up to $120 \mathrm{~kg} \mathrm{~N}$ ha $^{-1}$ gave significantly higher number of baby cob plant $^{-1}$ and baby corn yield (21.9 and 7.9\%) over 60 and $90 \mathrm{~kg} \mathrm{~N} \mathrm{ha}{ }^{-1}$, respectively. At Umiam (Meghalaya), Majumdar et al., (2002) reported that maize yield increased 
significantly with increasing levels of nitrogen application up to $100 \mathrm{~kg} \mathrm{~N} \mathrm{ha}{ }^{-1}$. Luikham et al., (2003) noticed that increasing levels of nitrogen application up to $135 \mathrm{~kg} \mathrm{~N}$ $\mathrm{ha}^{-1}$ significantly increased cob and stover yield of baby corn. Similarly, Ayub et al., (2003) reported that application of increasing levels of nitrogen up to $120 \mathrm{~kg} \mathrm{~N} \mathrm{ha}{ }^{-1}$ recorded significant improvement in green fodder yield of maize. In Bangladesh, Alam and Islam (2003) while assessing effect of different levels of nitrogen on maize cv. Barnali reported significant increase 1000grain weight as well as grain and stover yield with application of increasing levels of nitrogen up to $120 \mathrm{~kg} \mathrm{~N} \mathrm{ha}^{-1}$. At New Delhi, studying the response of maize to different levels of nitrogen, Banarjee et al., (2004) reported that application of increasing levels of nitrogen significantly increased grain yield up to $150 \mathrm{~kg} \mathrm{~N} \mathrm{ha}^{-1}$. Similarly, Maurya et al., (2005) noticed that application of $150 \mathrm{~kg} \mathrm{~N}$ $\mathrm{ha}^{-1}$ significantly increased number of cobs plant $^{-1}$, length of cobs, number of grains $\mathrm{cob}^{-1}$ and 1000-grain weight in maize but it remained at par with $100 \mathrm{~kg} \mathrm{~N} \mathrm{ha}^{-1}$.

In Turkey, Oktem and Oktem (2005) evaluated the response of maize to various doses of nitrogen $(150,200,250,300$ and 350 $\mathrm{kg} \mathrm{N} \mathrm{ha}{ }^{-1}$ ) and reported that increasing levels of nitrogen up to $350 \mathrm{~kg} \mathrm{~N}^{-1}$ significantly increased yield components i.e. ear length, ear diameter and single fresh ear weight. At Coimbatore working on baby corn, Muthukumar et al., (2005) reported that the significantly higher cob yield with increasing levels of nitrogen up to $150 \mathrm{~kg} \mathrm{~N} \mathrm{ha}{ }^{-1}$. Similarly, Bindhani et al., (2005) noticed significant increase in marketable fresh cob weight, length as well as girth of baby cob with application of increasing levels of nitrogen up to $120 \mathrm{~kg} \mathrm{~N} \mathrm{ha}^{-1}$. They also noted that $120 \mathrm{~kg} \mathrm{~N} \mathrm{ha}^{-1}$ resulted in highest baby corn yield, which was 28.6, 52.2 and $178 \%$ higher than 80,40 and $0 \mathrm{~kg} \mathrm{~N} \mathrm{ha}{ }^{-1}$, respectively. The green fodder yield followed similar trend.

Working at Palampur, Choudhary et al., (2006), reported that increasing levels of nitrogen application up to $120 \mathrm{~kg} \mathrm{~N} \mathrm{ha}^{-1}$ significantly increased grain and fodder yield of maize. In China, Xie et al., (2006) working on maize, reported that 100 -seed weight and grain yield were increased significantly with increasing rates of nitrogen application up to $180 \mathrm{~kg} \mathrm{~N} \mathrm{ha}{ }^{-1}$. According to Bakht et al., (2006) significantly higher cobs plant ${ }^{-1}$, grains $\mathrm{cob}^{-1}$, grain and biological yield of maize were recorded with increasing levels of nitrogen application up to $200 \mathrm{~kg} \mathrm{~N} \mathrm{ha}{ }^{-1}$. Similarly, significant enhancement in cob length and girth, grain weight $\mathrm{cob}^{-1}$, grain and stover yield of maize was noted with application of increasing levels of nitrogen up to $180 \mathrm{~kg} \mathrm{~N} \mathrm{ha}^{-1}$ (Ram et al., 2006). A field experiment was conducted at Umiam to study the effect of different nitrogen doses on baby corn cv. Vijay composite by Panwar and Munda (2006) and they observed that increasing levels of nitrogen up to $80 \mathrm{~kg} \mathrm{~N}$ ha ${ }^{1}$ produced significantly higher baby corn as well as fodder yield. Significantly higher grain yield of maize was recorded with increasing levels of nitrogen application up to $120 \mathrm{~kg} \mathrm{~N} \mathrm{ha}^{-1}$ (Meena et al., 2007a). Jan et al., (2007) reported significant increase in grain and stalk yield of maize to the nitrogen application as high as $300 \mathrm{~kg} \mathrm{~N} \mathrm{ha}{ }^{-1}$. At Junagadh during winter season of 2005-06 on sandy loam soil, Meena et al., (2007b) studied the response of maize to levels of $\mathrm{N}(0,40,80$ and $120 \mathrm{~kg} \mathrm{~N} \mathrm{ha}^{-1}$ ) and reported that cob length and cob diameter as well as grain and straw yield increased significantly with increasing levels of nitrogen application up to $120 \mathrm{~kg} \mathrm{~N} \mathrm{ha}^{-1}$. Similar responses of maize to the application of 100 to $140 \mathrm{~kg} \mathrm{~N} \mathrm{ha}^{-1}$ were reported by Bindhani et al., (2007), Sujatha et al., (2008) and Siam et al., (2008).According to Kumar (2009) cob length, cob girth and 
grains ear ${ }^{-1}$ were recorded significantly higher with nitrogen application up to $80 \mathrm{~kg} \mathrm{~N} \mathrm{ha}^{-1}$ but cob girth continued to improve further with nitrogen application up to $120 \mathrm{~kg} \mathrm{~N} \mathrm{ha}^{-1}$. Each successive increase in nitrogen level from $0-120 \mathrm{~kg} \mathrm{~N}^{-1}$ significantly enhanced grain and stover yield of maize to the tune of $38.2,64.9$ and 82.2 and $34.7,54.7$ and $66.6 \%$ with application of 40,80 and $120 \mathrm{~kg} \mathrm{~N} \mathrm{ha}^{-1}$, respectively over control. Working on popcorn Kunjir et al., (2009) noticed that length and girth of cob, green cob and green biomass yield increased significantly with increasing levels of nitrogen application up to $225 \mathrm{~kg} \mathrm{~N} \mathrm{ha}^{-1}$.

Working at Allahabad on baby corn, Rao et al., (2009) reported significant increase in baby cobs plant ${ }^{-1}$, baby cob weight, baby cob yield and green fodder yield with increasing levels of nitrogen application up to $120 \mathrm{~kg} \mathrm{~N}$ $\mathrm{ha}^{-1}$. At Bahraich (UP), Mishra et al., (2009) evaluated the effect of nitrogen levels on maize cv. Deccan-103 and noticed that increasing rates of nitrogen from $100-200 \mathrm{~kg}$ $\mathrm{N} \mathrm{ha}{ }^{-1}$ significantly increased rows $\mathrm{cob}^{-1}$, 1000-grain weight and grain yield. In Iran, Sharifi and Taghizadeh (2009) studied the effect of nitrogen levels on maize, noticed that maximum kernel ear ${ }^{-1}$, grains ear ${ }^{-1}$ row and grain yield were noted with application of increasing levels of nitrogen up to $200 \mathrm{~kg} \mathrm{~N}$ $\mathrm{ha}^{-1}$.In Turkey working on forage maize, Carpici et al., (2010) reported that dry fodder yield increased significantly with increasing rates of nitrogen up to $400 \mathrm{~kg} \mathrm{~N} \mathrm{ha}^{-1}$ but it remained statistically at par with $300 \mathrm{~kg} \mathrm{~N}$ ha 1. While evaluating the impact of nitrogen levels on maize at Peshawar (Pakistan), Arif et al., (2010a) noticed grains ear ${ }^{-1}, 1000$-grain weight, grain and biological yield improved constantly with increasing levels of nitrogen application from $0-160 \mathrm{~kg} \mathrm{ha}^{-1}$. Similarly, application of increasing nitrogen levels significantly improved grain and biological yield up to $120 \mathrm{~kg} \mathrm{~N} \mathrm{ha}^{-1}$ in maize cv. Azam (Arif et al., 2010b).
In a two years study on hybrid maize at Ludhiana, Mehta et al., (2011) reported that cob length, cob girth and grain yield were increased significantly with increasing levels of $\mathrm{N}$ up to $275 \mathrm{~kg} \mathrm{~N}$ over $200 \mathrm{~kg} \mathrm{~N} \mathrm{ha}^{-1}$ but remained comparable with $250 \mathrm{~kg} \mathrm{~N} \mathrm{ha}^{-1}$. At Jashipur (Odissa), Sahoo (2011) studying the effect of nitrogen application on baby corn noticed that baby corn yield increased significantly with increasing levels of nitrogen up to $120 \mathrm{~kg} \mathrm{~N} \mathrm{ha}^{-1}$ but fodder yield increased progressively up to $180 \mathrm{~kg} \mathrm{~N} \mathrm{ha}{ }^{-1}$, which remained at par with $120 \mathrm{~kg} \mathrm{~N}^{-1}$. At Faisalabad (Pakistan) working on maize, Khan et al., (2011) reported that significantly higher grains $\mathrm{cob}^{-1}, 1000$-grain weight and grain yield with application of increasing levels of nitrogen up to $300 \mathrm{~kg} \mathrm{~N} \mathrm{ha}{ }^{-1}$. According to Effa et al., (2011) maize var. Ashland recorded significantly higher grain yield with increasing $\mathrm{N}$ rates up to $120 \mathrm{~kg} \mathrm{~N}$ $\mathrm{ha}^{-1}$. They noticed that respective doses of nitrogen (40, 80 and $120 \mathrm{~kg} \mathrm{~N} \mathrm{ha}^{-1}$ ) gave yield increases of 12.6, 21.5 and $50.4 \%$ over control. Evaluating the impact of nitrogen levels on hybrid maize cv. Pionner-31 R 88, Wasaya et al., (2011) at Faisalabad (Pakistan) stated that grain weight $\mathrm{cob}^{-1}$ and grain yield were increased significantly with increasing levels of nitrogen up to $200 \mathrm{~kg} \mathrm{~N} \mathrm{ha}{ }^{-1}$. However, the yield increase due to application of $200 \mathrm{~kg} \mathrm{~N} \mathrm{ha}{ }^{-1}$ was $17 \%$ and $18.5 \%$ higher than 100 and $150 \mathrm{~kg} \mathrm{~N} \mathrm{ha}^{-1}$, respectively. At Shalimar (JK), assessing the effect of nitrogen levels on fodder maize cv.J-1006, Mahdi et al., (2012) reported that green fodder yield increased significantly with increasing levels of nitrogen application up to $120 \mathrm{~kg} \mathrm{~N} \mathrm{ha}{ }^{-1}$. Similarly, at Varanasi, Jeet et al., (2012), Jeet el al., (2017) noticed that the significantly higher cobs plant ${ }^{-1}$, cob length, cob diameter, cob weight, and grain yield of QPM with increasing levels of nitrogen up to $150 \mathrm{~kg} \mathrm{~N}$ $\mathrm{ha}^{-1}$.

According to Singh et al., (2012) yield attributes i.e. number of cobs, green cob 
weight, kernel $\operatorname{cob}^{-1}, 1000$-kernal weight, kernel recovery and barrenness (\%) in sweet corn were significantly influenced with application of nitrogen up to $150 \mathrm{~kg} \mathrm{~N}$ ha ${ }^{-1}$ but remained statistically on par with $120 \mathrm{~kg}$ $\mathrm{N} \mathrm{ha}{ }^{-1}$.They also noticed that successive levels of nitrogen application up to $120 \mathrm{~kg} \mathrm{~N}$ $\mathrm{ha}^{-1}$ markedly increased green cob and fresh corn yield, which remained at par with $150 \mathrm{~kg}$ $\mathrm{N} \mathrm{ha}^{-1}$. However, application $120 \mathrm{~kg} \mathrm{~N} \mathrm{ha}^{-1}$ enhanced the green cob yield by 7.7, 19.9, 33.9 and $128 \%$ over $90,60,30 \mathrm{~kg} \mathrm{~N}^{-1}$ and control. In case of green fodder yield, application of $120 \mathrm{~kg} \mathrm{~N} \mathrm{ha}^{-1}$ being at par with $150 \mathrm{~kg} \mathrm{~N} \mathrm{ha}{ }^{-1}$ markedly enhanced green fodder yield to the tune of $127.5,51.5,24.1$ and $6.3 \%$ over control, 30,60 and $90 \mathrm{~kg} \mathrm{~N}$ ha 1 , respectively. Working on maize at Hamirpur (UP) Verma et al., (2012) noticed that cob diameter, weight of cobs plant ${ }^{-1}$ and grain yield increased significantly with application of increasing levels of nitrogen up to $150 \mathrm{~N} \mathrm{ha}^{-1}$.

The highest level of nitrogen application i.e. $150 \mathrm{~kg} \mathrm{~N} \mathrm{ha}{ }^{-1}$ recorded 2.3 and $7.4 \%$ higher grain yield as compared to 100 and $50 \mathrm{~N} \mathrm{ha}^{-1}$, respectively. At Vadodara (Gujarat) Raskar et al., (2012) found that application of 120 and $160 \mathrm{~kg} \mathrm{~N} \mathrm{ha}^{-1}$ were at par and produced significantly higher no. of cobs plant ${ }^{-1}$, cob length, no. of grains row $\mathrm{cob}^{-1}$, test weight, shelling percentage, grain and stover yield of maize as compared to $80 \mathrm{~kg} \mathrm{~N} \mathrm{ha}{ }^{-1}$. According to Jena et al., (2015) grain yield, stover yield and total dry matter production of QPM increase up to increasing level i.e. 240 $\mathrm{kg} \mathrm{ha}{ }^{-1}$. Singh et al., (2016a) studies the response of baby corn to integrated nutrient management results revealed that maximum baby corn length, baby corn girth, green cob weight, baby cob weight, number of cobs, baby corn yield and green fodder yield were recorded with application of 5t FYM $+100 \mathrm{~kg}$ $\mathrm{N}$ ha ${ }^{-1}$ followed by $100 \%$ recommended dose of nitrogen.

\section{Nutrient contents and their uptake}

Sridhar (1988) noticed that uptake of N, P and $\mathrm{K}$ in maize significantly increased with increasing levels of nitrogen up to $180 \mathrm{~kg} \mathrm{~N}$ ha $^{-1}$. Similarly, Thakur et al., (1998) reported that $\mathrm{N}$ uptake by green fodder increased significantly up to $150 \mathrm{~kg} \mathrm{~N}^{-1}$, whereas $\mathrm{N}$ uptake by baby corn was noted maximum at $200 \mathrm{~kg} \mathrm{~N} \mathrm{ha}^{-1}$. Working on maize at Umiam (Meghalaya), Majumdar et al., (2002) reported that increasing levels of nitrogen significantly increased $\mathrm{N}$ uptake of maize up to $100 \mathrm{~kg} \mathrm{~N} \mathrm{ha}^{-1}$. Nitrogen content in maize grain increased significantly with increasing doses of Nup to $100 \mathrm{~kg} \mathrm{~N} \mathrm{ha}^{-1}$ (Adiloglu and Saglam, 2005).

Application of nitrogen up to $150 \mathrm{~kg} \mathrm{~N} \mathrm{ha}{ }^{-1}$ significantly enhanced $\mathrm{N}$ content and uptake by grain and stover of maize (Maurya et al., 2005). Similarly, nitrogen content in baby corn and green fodder increased significantly with increasing levels of nitrogen up to 120 $\mathrm{kg} \mathrm{N} \mathrm{ha}{ }^{-1}$ (Bindhani et al., 2005). Application of increasing levels of nitrogen from 0 to 120 $\mathrm{kg} \mathrm{ha}^{-1}$ significantly increased $\mathrm{N}$ uptake in baby corn (Panwar and Munda, 2006). Each subsequent increase in nitrogen level up to $120 \mathrm{~kg} \mathrm{~N} \mathrm{ha}{ }^{-1}$ significantly increased $\mathrm{N}$ content and uptake in baby corn (Bindhani et al., 2007). Similarly, Kumar (2009) noticed each successive increase in nitrogen level from 0 to $120 \mathrm{~kg} \mathrm{ha}^{-1}$ significantly improved $\mathrm{N}$ content in grain yield of pop corn. Mahdi $e t$ al., (2012) reported significantly higher $\mathrm{N}$ and $\mathrm{Zn}$ content as well as uptake in fodder maize with application of increasing levels of nitrogen up to $120 \mathrm{~kg} \mathrm{~N}^{-1}$. Jeet et al., (2012) noticed significantly higher N, P, K, and $\mathrm{S}$ content in grains and stover of maize with application of $150 \mathrm{~kg} \mathrm{~N} \mathrm{ha}^{-1}$ over $50 \mathrm{~kg}$ $\mathrm{N} \mathrm{ha}^{-1}$ but remained at par with $100 \mathrm{~kg} \mathrm{~N} \mathrm{ha}^{-1}$. However, total uptake of $\mathrm{N}, \mathrm{P}, \mathrm{K}$ and $\mathrm{S}$ significantly increased with increasing levels of $\mathrm{N}$ application up to $150 \mathrm{~kg} \mathrm{Nha}^{-1}$. 


\section{Quality}

Leary and Rehm (1990) reported that crude protein content in corn silage significantly increased with application of increasing levels of nitrogen up to $225 \mathrm{~kg} \mathrm{~N}^{-1}$. Similarly, protein content in maize grain increased significantly with each successive increase in nitrogen levels up to $200 \mathrm{~kg} \mathrm{~N} \mathrm{ha}^{-1}$ (Sarwar 1993). Application of $180 \mathrm{~kg} \mathrm{~N} \mathrm{ha}{ }^{-1}$ significantly increased crude protein content in baby corn over $120 \mathrm{~kg} \mathrm{ha}^{-1}$ but it remained par with $150 \mathrm{~kg} \mathrm{~N}^{-1}$ (Rajendran and Singh 1999).Majumdar et al., (2002) reported that increasing levels of nitrogen up to $100 \mathrm{~kg} \mathrm{~N}$ $\mathrm{ha}^{-1}$ significantly increased crude protein content in maize. Similarly, significant improvement in crude protein and fibre content were noted with $120 \mathrm{~kg} \mathrm{~N}^{-1}$ (Ayub et al., 2003).Maurya et al., (2004) noted that increasing nitrogen levels from $0-150 \mathrm{~kg} \mathrm{~N}$ $\mathrm{ha}^{-1}$ significantly increased protein content in maize grain. Significantly higher crude protein content and protein yield in maize were recorded with application of increasing rates of $\mathrm{N}$ up to $200 \mathrm{~kg} \mathrm{~N} \mathrm{ha}^{-1}$ (Keskin et al., 2005).

Rasheed et al., (2004) noticed significantly higher protein content in maize grain $(9.9 \%)$ with application of $150 \mathrm{~kg} \mathrm{~N}+20 \mathrm{~kg} \mathrm{~S}$ ha ${ }^{1}$.Application of increasing levels of nitrogen up to $150 \mathrm{~kg} \mathrm{~N}^{-1}$ significantly increased total sugar, starch, protein and crude protein content in baby corn (Muthukumar et al., 2005).Bindhani et al., (2005) also reported that protein content and protein yield of baby corn were increased significantly with application of increasing levels of nitrogen up to $120 \mathrm{~kg} \mathrm{~N} \mathrm{ha}{ }^{-1}$. Similarly, increasing nitrogen levels up to $80 \mathrm{~kg} \mathrm{~N} \mathrm{ha}^{-1}$ recorded significantly higher grain protein content in maize (Hani et al., 2006). Ram et al., (2006) reported significant improvement in carbohydrate, starch and protein yield with application of increasing levels of nitrogen up to $180 \mathrm{~kg} \mathrm{~N} \mathrm{ha}^{-1}$. Similarly, application of 120 $\mathrm{kg} \mathrm{N} \mathrm{ha}{ }^{-1}$ significantly increased protein content and its yield over $80 \mathrm{~kg} \mathrm{~N} \mathrm{ha}^{-1}$ (Meena et al., 2007). Bindhani et al., (2007) noticed that application of $120 \mathrm{~kg} \mathrm{~N}^{-1} \mathrm{~h}^{-1}$ significantly increased protein content and protein yield of baby corn. Working on popcorn, Kumar (2009) noticed that increasing levels of nitrogen application significantly improved grain protein content up to $80 \mathrm{~kg} \mathrm{~N} \mathrm{ha}{ }^{-1}$. Mishra et al., (2009) reported that application of increasing levels of nitrogen up to $200 \mathrm{~kg}$ $\mathrm{N}$ ha ${ }^{-1}$ significantly increased protein content in maize grain. Carpici et al., (2010) observed significantly higher crude protein content with application of $400 \mathrm{~kg} \mathrm{~N} \mathrm{ha}^{-1}$ over $200 \mathrm{~kg} \mathrm{~N}$ $\mathrm{ha}^{-1}$ but it remained at par with $300 \mathrm{~kg} \mathrm{ha}^{-}$ ${ }^{1}$.Verma (2011) noticed that protein content in maize grain significantly increased with increasing levels of nitrogen application up to $150 \mathrm{~kg} \mathrm{~N} \mathrm{ha}{ }^{-1}$. However, Khan et al., (2011) reported protein content in maize grain was enhanced with increasing levels of nitrogen up to $300 \mathrm{~kg} \mathrm{~N} \mathrm{ha}^{-1}$. Whereas, Mahdi et al., (2012) noticed that application of $120 \mathrm{~kg} \mathrm{~N}$ $\mathrm{ha}^{-1}$ significantly increased crude protein, protein yield and crude fibre content over 90 $\mathrm{kg} \mathrm{N} \mathrm{Na}^{-1}$. Similarly, Jeet et al., (2012) also reported that protein content in grain of maize increased significantly with increasing doses of nitrogen up to $150 \mathrm{~kg} \mathrm{~N} \mathrm{ha}^{-1}$.

Neupane et al., (2011b) found significantly higher protein, carbohydrate and sugar content in baby corn with the application of $75 \% \mathrm{~N}$ through urea $+25 \% \mathrm{~N}$ through FYM. Neupane et al.,(2012b) observed significantly higher chlorophyll contents in leaves, protein, carbohydrate and sugar content in baby corn cobs in nitrogen source of $75 \% \mathrm{~N}$ through urea $+25 \% \mathrm{~N}$ through FYM followed by $100 \% \mathrm{~N}$ through urea in baby corn (Zea maysL.) as influenced by N sources. Singh $e t$ al., (2016a) carried out an field experiment at Amritsar to assess the effect of integrated nutrient management on yield and quality of baby corn results showed that application of 5t $\mathrm{FYM}+100 \%$ recommended dose of in 
organic nitrogen improved the total soluble sugar and protein content which was at par with $100 \%$ recommended dose of in organic nitrogen and significantly higher over rest of the treatments.

Sarwar (1993) reported significantly higher net return with increase in nitrogen levels up to $200 \mathrm{~kg} \mathrm{~N} \mathrm{ha}^{-1}$. Thakur et al., (1997) also noticed significantly higher net return with application of $200 \mathrm{~kg} \mathrm{~N} \mathrm{ha}^{-1}$, which was 5.2 , 23.8, 57.6 and $117.7 \%$ higher over 150, 100, $50 \mathrm{~kg} \mathrm{~N} \mathrm{ha}{ }^{-1}$ and control but maximum net return rupess ${ }^{-1}$ invested was noted with 150 $\mathrm{kg} \mathrm{N} \mathrm{ha}^{-1}$. Working on baby corn Pandey et al., (2000) noticed significantly higher net return and $\mathrm{B}$ : $\mathrm{C}$ ratio with application of increasing levels of nitrogen up to $120 \mathrm{~kg} \mathrm{~N}$ $\mathrm{ha}^{-1}$. Net return and B: C ratio in baby corn was also noted significantly higher with application of $120 \mathrm{~kg} \mathrm{~N} \mathrm{ha}^{-1}$. The increases were $289.2,69.8$ and $39.1 \%$ in net return and 235.2, 57.7 and $34.1 \%$ in $\mathrm{B}$ : $\mathrm{C}$ ratio as compared to 0,40 and $80 \mathrm{~kg} \mathrm{~N} \mathrm{ha}{ }^{-1}$, respectively (Bindhani et al., 2005). Application of increasing levels of nitrogen up to $150 \mathrm{~kg} \mathrm{~N}^{-1}$ recorded significantly higher net profit and B: C ratio in maize (Maurya et al., 2005).Panwar and Munda (2006) reported that application of $120 \mathrm{~kg} \mathrm{~N}$ $\mathrm{ha}^{-1}$ recorded significantly higher net return of baby corn, which was 6,25 and $63.2 \%$ higher with 80,40 and $0 \mathrm{~kg} \mathrm{~N}^{-1}$, respectively. In another study it was found that addition of $180 \mathrm{~kg} \mathrm{~N} \mathrm{ha}^{-1}$ gave significantly higher gross, net return and $\mathrm{B}$ : $\mathrm{C}$ ratio over $120 \mathrm{~kg} \mathrm{~N}^{-1}$ and lower doses (Ram et al., 2006). Similarly, Bindhani et al., (2007) and Meena et al., (2007) reported significantly higher net return and B: C ratio with increasing levels of nitrogen application up to $120 \mathrm{~kg}$ ha ${ }^{1}$.According to Kumar (2009) significant enhancement in net return of maize to the tune of 69.1, 118.9 and 146.1 and 49.1, 84.6 and $109.5 \%$ with 40,80 and $120 \mathrm{~kg} \mathrm{~N}^{-1}$ over control were recorded during 2005 and
2006, respectively. Mahdi et al., (2012) noticed that application of nitrogen up to 120 $\mathrm{kg} \mathrm{N} \mathrm{ha}{ }^{-1}$ recorded significant improvement in net return and $\mathrm{B}$ : $\mathrm{C}$ ratio in fodder maize over $90 \mathrm{~kg} \mathrm{~N} \mathrm{ha}^{-1}$. Singh et al., (2012) reported that application of $120 \mathrm{~kg} \mathrm{~N}^{-1}$ improved net return and net return rupees ${ }^{-1}$ invested in sweet corn over control but remained comparable with $150 \mathrm{~kg} \mathrm{~N} \mathrm{ha}{ }^{-1}$. Jeet et al., (2014) reported highest net return and B: C ratio was recorded under $150 \mathrm{~kg} \mathrm{~N} / \mathrm{ha}$ in QPM hybrids under different nitrogen and sulphur levels.

Application of increasing nitrogen levels up to $140 \mathrm{~kg} \mathrm{~N}^{-1}$ significantly increased $\mathrm{N}, \mathrm{P}$ and $\mathrm{K}$ content in soil (Siam et al., 2008). Similarly, Sujatha et al., (2008) reported significantly higher available $\mathrm{N}, \mathrm{P}$ and $\mathrm{K}$ contents in soil with increasing levels of nitrogen up to $100 \%$ RDN. Total availability and removal of $\mathrm{N}$ were noted maximum with application of increasing levels of nitrogen up to $120 \mathrm{~kg} \mathrm{~N} \mathrm{ha}^{-1}$ (Kumar 2009). Similarly, available $\mathrm{N}, \mathrm{P}, \mathrm{K}$ and $\mathrm{S}$ status in soil were significantly improved with increasing nitrogen levels up to $150 \mathrm{~kg} \mathrm{Nha}^{-1}$ (Jeet et al., 2012).

\section{Effect of phosphorus}

Phosphorus being the constituents of sugar, phosphatases, ADP and ATP plays an important role in energy transformations and it is also involved in the basic reactions of photosynthesis. Review regarding this nutrient has been cited in this section.

\section{Growth characters}

Rasheed et al., (2004) noticed significantly taller plants, higher flag leaf area and days to silking with application of $60 \mathrm{~kg} \mathrm{Pha}^{-1}$ over control. Khan et al., (2005) at Multan (Pakistan) studied the effect of different levels of phosphorus on maize cv. M-6240 and 
noted that maize fertilized with $100 \mathrm{~kg} \mathrm{P}_{2} \mathrm{O}_{5}$ $\mathrm{ha}^{-1}$ recorded maximum plant height as compared to $75 \mathrm{~kg} \mathrm{P}_{2} \mathrm{O}_{5} \mathrm{ha}^{-1}$. In a field trial at New Delhi on chickpea-baby corn sequence, Gangaiah and Ahlawat (2008) observed that baby corn cv. PEHM-2 after chickpea fertilized with $26.4 \mathrm{~kg} \quad \mathrm{P} \quad \mathrm{ha}^{-1}$ noted significantly taller plants over $13.2 \mathrm{~kg} \mathrm{P}$ ha ${ }^{1}$.Similarly, working on maize Raskar et al., (2012) reported that increasing level of phosphorus increased the plant height up to $80 \mathrm{~kg} \mathrm{ha}^{-1}$ but on par with $60 \mathrm{~kg} \mathrm{ha}^{-1}$ and significantly superior over $40 \mathrm{~kg} \mathrm{ha}^{-1}$. Jena et al., (2015) working on quality protein maize at Rajendranagar, Hyderabad reported that application of $100 \mathrm{~kg} \mathrm{P} \mathrm{ha}^{-1}$ produced taller plant and LAI over rest of the phosphorus levels i.e. 0, 60 and $80 \mathrm{~kg} \mathrm{ha}^{-1}$.

\section{Yield attributes and yields}

At New Delhi, Arya and Singh (2000), studying the response of maize to different levels of phosphorus $(0,30,60$ and $90 \mathrm{~kg}$ $\mathrm{P}_{2} \mathrm{O}_{5} \mathrm{ha}^{-1}$ ) reported significantly higher grain and stover with application of increasing levels of phosphorus up to $90 \mathrm{~kg}_{2} \mathrm{O}_{5}$ ha ${ }^{1}$.The magnitude of increase in grain and stover yield were 17.2, 54.4 and $82.3 \%$ and $6.5,37.3$ and $59.6 \%$ with 30,60 and $90 \mathrm{~kg}$ $\mathrm{P}_{2} \mathrm{O}_{5} \mathrm{ha}^{-1}$ over control, respectively. According to Venkatesh et al., (2002) significantly higher test weight and maize yield were recorded with application of increasing levels of phosphorus up to $60 \mathrm{~kg}$ $\mathrm{P}_{2} \mathrm{O}_{5}$. At Udaipur (Rajasthan), Mehta et al., (2005) evaluating the response of maize to different phosphorus levels $(20,40$ and $60 \mathrm{~kg}$ $\mathrm{P}_{2} \mathrm{O}_{5}$ ha $^{-1}$ ) noticed that cobs plant ${ }^{-1}$, grain weight $\mathrm{cob}^{-1}$, seed yield and stover yield increased significantly with increasing levels of phosphorus up to $60 \mathrm{~kg} \mathrm{P}_{2} \mathrm{O}_{5} \mathrm{ha}^{-1}$. Working on maize, Khan et al., (2005) reported that maize crop fertilized with increasing levels of phosphorus up to $75 \mathrm{~kg}_{2} \mathrm{O}_{5} \mathrm{ha}^{-1}$ recorded maximum grain weight $\mathrm{cob}^{-1}$, cob weight as well as grain and stover yield. Dixit (2006) while evaluating the response of maize to levels of phosphorus $(0,13,26$ and $39 \mathrm{~kg} \mathrm{P}$ $\mathrm{ha}^{-1}$ ) noticed significant increase in grain yield with increasing levels of phosphorus up to $39 \mathrm{~kg} \mathrm{P} \mathrm{ha}{ }^{-1}$. At Peshawar (Pakistan) Ahmad et al., (2007) studied the response of maize to different levels of phosphorus (60, 90 and $120 \mathrm{~kg} \mathrm{P}_{2} \mathrm{O}_{5} \mathrm{ha}^{-1}$ ) and noticed that grain yield was increased significantly with increasing levels of phosphorus application up to $120 \mathrm{~kg} \mathrm{P}_{2} \mathrm{O}_{5} \mathrm{ha}^{-1}$. Working at Vidarbha (Maharashtra), Ghodpage et al., (2008) noticed that application of phosphorus@40, 60 and $80 \mathrm{~kg} \mathrm{P} \mathrm{ha}^{-1}$ increased maize yield by 11,18 and $20 \%$, respectively over control. According to Gangaiah and Ahlawat (2008) significantly higher baby cobs plant ${ }^{-1}$, baby cob length as well as baby cob, baby corn and fodder yield were recorded with increasing levels of phosphorus application up to $26.4 \mathrm{~kg}$ $\mathrm{P}$ ha $^{-1}$. At Vadodara, Raskar et al., (2012) reported that application of 80 and $60 \mathrm{~kg} \mathrm{P}_{2} \mathrm{O}_{5}$ $\mathrm{ha}^{-1}$ were at par and gave significantly higher No. of cobs plant ${ }^{-1}$, cob length, No. of grains row $\mathrm{cob}^{-1}$, test weight, shelling percentage, grain and stover yield of maize as compared to $40 \mathrm{~kg} \mathrm{P}_{2} \mathrm{O}_{5} \mathrm{ha}^{-1}$. Similarly, at Kota (Rajasthan), Shivran et al., (2013) reported significantly higher grain and stover yield of maize with application of increasing levels up to $40 \mathrm{~kg} \mathrm{P}_{2} \mathrm{O}_{5} \mathrm{ha}^{-1}$.Jena et al., (2015) reported that maize crop fertilized with levels of phosphorus up to $100 \mathrm{~kg} \mathrm{ha}^{-1}$ gave maximum plant height and LAI but this level at par with $80 \mathrm{~kg} \mathrm{P} \mathrm{ha}{ }^{-1}$.

\section{Nutrient contents and their uptake}

Application of increasing levels of phosphorus up to $90 \mathrm{~kg} \mathrm{P}_{2} \mathrm{O}_{5} \mathrm{ha}^{-1}$ significantly increased N, P and $\mathrm{K}$ uptake in maize (Arya and Singh 2000). According to Venkatesh et al., (2002) application of increasing levels of phosphorus up to $60 \mathrm{~kg} \mathrm{P}_{2} \mathrm{O}_{5} \mathrm{ha}^{-1}$ recorded significantly higher $\mathrm{P}$ uptake in maize. 
However, Mehta et al., (2005) reported that $\mathrm{N}, \mathrm{P}$ and $\mathrm{S}$ uptake in maize increased significantly with increasing levels of phosphorus up to $60 \mathrm{~kg} \mathrm{P}_{2} \mathrm{O}_{5} \mathrm{ha}^{-1}$. Dixit (2006) noticed that uptake of N, P and K by grain and stover of maize significantly increased due to increasing level of phosphorus up to $39 \mathrm{~kg} \mathrm{P} \mathrm{ha}^{-1}$. Ghodpage et al., (2008) noticed that $\mathrm{N}$ and $\mathrm{P}$ content in grain of maize increased significantly with increasing levels of $\mathrm{P} 80 \mathrm{~kg} \mathrm{P} \mathrm{ha}^{-1}$.

\section{Quality}

Arya and Singh (2000) noticed that application of increasing levels of phosphorus up to $90 \mathrm{~kg} \mathrm{P}_{2} \mathrm{O}_{5} \mathrm{ha}^{-1}$ significantly increased protein yield of maize. Similarly, crude protein content in maize increased significantly with application of $80 \mathrm{~kg} \mathrm{P} \mathrm{ha}^{-1}$ but the reverse trend was observed with respect to starch content (Ghodpage et al., 2008).

\section{Economics}

Sahoo and Panda (2001) working on baby corn obtained significantly higher net return with application of $26.2 \mathrm{~kg} \mathrm{P} \mathrm{ha}^{-1}$ over $17.5 \mathrm{~kg}$ $\mathrm{P} \mathrm{ha}^{-1}$ but it remained at par with $35 \mathrm{~kg} \mathrm{P} \mathrm{ha}^{-1}$.

\section{Effect of potassium}

Potassium activates number of enzymes, including those involved in the synthesis of carbohydrates and resistance to diseases and adverse environmental conditions. It also improves the utilization of nitrogen and phosphorous and plays an important role in growth and reproductive development of plants. Potassium is the cation most abundantly available in the cytoplasm that regulates osmotic potential of cells and tissues of glycophytic plant species (Marschner 1995).

\section{Growth characters}

Kalpana and Krishnarajan (2002) studied the effect of levels of $\mathrm{K}$ application on baby corn and noticed significantly higher plant height, LAI and dry matter production with application of $50 \mathrm{~kg} \mathrm{~K} \mathrm{ha}^{-1}$ over $40 \mathrm{~kg} \mathrm{~K} \mathrm{ha}^{-1}$. Asif et al., (2007) carried out an field experiment at Peshawar, Pakistan to study the penology and leaf area of spring maize $\mathrm{cv}$. Azam to different levels of potassium $(0,30$, 60 and $90 \mathrm{~kg} \mathrm{~K} \mathrm{ha}^{-1}$ ) and reported that tasseling, silking and physiological maturity were delayed when potassium application was increased up to $60 \mathrm{~kg} \mathrm{~K} \mathrm{ha}^{-1}$, while increase in potassium level up to $90 \mathrm{~kg} \quad \mathrm{~K} \quad \mathrm{ha}^{-1}$ significantly enhanced tasseling, silking and maturity as well as flag leaf area and leaf area.

Amanullah et al., (2016) conducted a field experiment at Peshawar, Pakistan results revealed that among the foliar $\mathrm{K}$ levels, plant height, mean single leaf area and LAI were obtained with were recorded with the application of $2 \%$ foliar spray.

\section{Yield attributes and yield}

Kalpana and Krishnarajan (2002) reported significantly higher cobs plant ${ }^{-1}$, cob length, cob width as well as cob and stover yield of baby corn with $50 \mathrm{~kg} \mathrm{~K} \mathrm{ha}^{-1}$ as compared to $40 \mathrm{~kg} \mathrm{~K} \mathrm{ha}{ }^{-1}$. According to Asif et al., (2007) yield of maize enhanced significantly with application of increasing levels of potassium up to $90 \mathrm{~kg} \mathrm{ha}^{-1}$. Amanullah et al., (2016) revealed that among the foliar K levels, 1000grain weight, No. of grains ear $^{-1}$ and harvest index were obtained with were recorded with the application of $2 \%$ foliar spray, whereas, the highest grain yield and shelling percentage was recorded with the foliar spray of K@3\%. 


\section{Nutrient contents and their uptake}

Kalpana and Krishnarajan (2002) noticed that application of increasing levels of potassium up to $50 \mathrm{~kg} \mathrm{~K} \mathrm{ha}^{-1}$ significantly increased $\mathrm{N}$ and $\mathrm{K}$ uptake in baby corn.

\section{Quality}

While, Kalpana and Krishnarajan (2002) noticed increasing level of potassium application up to $50 \mathrm{~kg} \mathrm{~K} \mathrm{ha}{ }^{-1}$ significantly increased crude protein content in baby corn.

\section{Effect of sulphur}

Sulphur has long been recognized as an essential element for plant and animal. It is known to be indispensable for many reactions in all living cells. Literatures regarding the effect of $S$ on the performance of maize crop have been summarized in this section.

\section{Growth characters}

Sinha et al., (1995) noticed significant improvement in plant height and dry matter production of maize with application of increasing levels of sulphur up to $40 \mathrm{~kg} \mathrm{~S} \mathrm{ha}^{-1}$. Application of increasing levels of sulphur up to $40 \mathrm{~kg} \mathrm{~S}$ ha $^{-1}$ significantly enhanced the plant height, no. of green leaf plant ${ }^{-1}$, leaf area index and dry matter of maize (Sakal et al., 2000). Dhananjaya and Basavaraj (2002) reported similar response of maize to increasing levels of sulphur application of 45

$\mathrm{kg} \mathrm{ha}{ }^{-1}$. Similar response maize to sulphur application was reported by Sankaran et al., (2002). Patel et al., (2004) reported that the growth attributing characters of maize viz. plant height, number of green leaf, leaf area index and dry matter plant ${ }^{-1}$ increased with increasing levels of sulphur up to $60 \mathrm{~kg} \mathrm{~S} \mathrm{ha}^{-1}$ (Mehta et al., 2005). Similarly, Ram et al., (2006) also reported that plant height, leaf area index and dry matter production of maize increased significantly with increasing levels of sulphur up to $60 \mathrm{~kg} \mathrm{~S} \mathrm{ha}{ }^{-1}$. Bharathi and Poongothai (2008) noticed significantly higher growth attributes of maize with increasing levels of sulphur application up to $45 \mathrm{~kg} \mathrm{~S} \mathrm{ha}^{-1}$ but it remained statistically on par with $30 \mathrm{~kg} \mathrm{~S} \mathrm{ha}^{-1}$. A field experiment on maize was conducted on sandy loam soil during kharif season of 2000-2004 at IIPR Kanpur by Srinivasarao et al., (2010) and they noticed significantly higher plant height and dry matter production with increasing level of sulphur application up to $20 \mathrm{~kg} \mathrm{~S} \mathrm{ha}$. Working on QPM maize at Varanasi, Jeet et al., (2012) reported significantly higher plant height, green leaves plant $^{-1}$, leaf area index and dry matter plant $^{-1}$ with application of increasing levels of sulphur up to $45 \mathrm{~kg} \mathrm{~S}^{-}{ }^{-}$ 1. Kumar et al., (2016c) reported that significant increase in root length; root dry weight and root volume at respective stage of crop growth were recorded with each increment of sulphur up to $50 \mathrm{~kg} \mathrm{~S} \mathrm{ha}^{-1}$.

\section{Yield attributes and yields}

Leary and Rehm (1990) evaluated the response of corn with different levels of sulphur $\left(0,10,20,40 \mathrm{~kg} \mathrm{~S} \mathrm{ha}^{-1}\right)$ and reported that application of $10 \mathrm{~kg} \mathrm{~S} \mathrm{ha}{ }^{-1}$ was found adequate to achieve the highest yield. At Samastipur (Bihar) working on maize, Sinha et al., (1995) reported that grain and stover yield increased significantly with application of increasing levels of sulphur up to $40 \mathrm{~kg} \mathrm{~S}$ $\mathrm{ha}^{-1}$. Sakal et al., (2000) noticed that application of sulphur up to $40 \mathrm{~kg} \mathrm{ha}^{-1}$ significantly enhanced grain and stalk yield of maize over control. Working at Umiam (Meghalaya) on maize, Majumdar et al., (2002) noticed that increasing levels of sulphur application up to $20 \mathrm{~kg} \mathrm{~S} \mathrm{ha}^{-1}$ significantly increased maize yield. At Kanpur, Dwivedi et al., (2002) reported significantly higher yield of maize with increasing levels of S up to $30 \mathrm{~kg} \mathrm{~S} \mathrm{ha}^{-1}$. Yield 
components viz. cob length and girth and grain weight $\mathrm{cob}^{-1}$ of maize increased significantly with increasing levels of sulphur up to $45 \mathrm{~kg} \mathrm{~S} \mathrm{ha}^{-1}$ (Dhananjaya and Basavaraj 2002). Alam and Islam (2003) at Bangladesh assessed the effect of levels of sulphur application on maize cv. Barnali and reported significantly higher grain yield with application of increasing levels of sulphur up to $20 \mathrm{~kg} \mathrm{~S} \mathrm{ha}{ }^{-1}$. Similarly, Rasheed et al., (2004) also recorded significantly better yield attributes of maize viz. grain ear $^{-1}$ and grain weight $\mathrm{ear}^{-1}$ with application of $20 \mathrm{~kg}$ of S ha ${ }^{-1}$ over $15 \mathrm{~kg} \mathrm{~S} \mathrm{ha}^{-1}$. Working at Udaipur (Rajasthan) Mehta et al., (2005)studied the response of maize to application of different of sulphur levels $\left(0,30\right.$ and $\left.60 \mathrm{~kg} \mathrm{~S} \mathrm{ha}^{-1}\right)$ and noticed that cob plant ${ }^{-1}$, cob weight, grain and stover yield were significantly increased with increasing levels of sulphur up to $60 \mathrm{Kg} \mathrm{S} \mathrm{ha}^{-1}$. Similarly, significantly improved yield components of maize viz. cobs plant ${ }^{-1}$, length of cobs and grains $\operatorname{cob}^{-1}$ were improved with $45 \mathrm{~kg} \mathrm{~S} h a^{-1}$ over lower doses (Maurya et al., 2005).

Ram et al., (2006) noticed that application of sulphur significantly increased yield attributes of maize viz. cob length, and girth, grain weigh $\mathrm{cob}^{-1}$ as well as grain and stover yield up to $60 \mathrm{~kg} \mathrm{~S} \mathrm{ha}^{-1}$. At Peshawar (Pakistan), Khan et al., (2006) assessed the effect of different levels of sulphur $(0,20,40,60,80$, 100 and $120 \mathrm{~kg} \mathrm{~S}^{-1}$ ) on maize and reported that application of increasing levels of sulphur up to $60 \mathrm{~kg} \mathrm{~S}$ ha $^{-1}$ produced significantly higher fresh and dry matter yield as well as grain and stover yield. At Chitwan valley Rampur, Adhikary and Pandey (2007) evaluated the response of maize to levels of sulphur $\left(0,10,20,30\right.$ and $\left.40 \mathrm{~kg} \mathrm{~S} \mathrm{ha}^{-1}\right)$ noticed that sulphur application at $20 \mathrm{Kg} \mathrm{S} \mathrm{ha}^{-1}$ significantly increased grain yield over control, which was $63.4 \%$.At Coimbatore, Bharathi and Poongothai (2008) noticed that cob length increased significantly with increasing rates of sulphur application up to $45 \mathrm{~kg} \mathrm{~S} \mathrm{ha}^{-1}$ but grain and stalk yield of maize were increased significantly only up to $30 \mathrm{~kg}$ $\mathrm{S} \mathrm{ha}^{-1}$. Srinivasarao et al., (2010) noticed that increasing levels of sulphur application to maize up to $20 \mathrm{~kg} \mathrm{~S}$ ha $^{-1}$ significantly increased cob length, cob girth, cob weight as well as seed and stover yield. At Varanasi working on quality protein maize hybrid, Jeet et al., (2012) noticed that cobs plant ${ }^{-1}$, cob length as well as grain and stover yield significantly increased with increasing levels of sulphur application up to $45 \mathrm{~kg} \mathrm{~S} \mathrm{ha}^{-1}$. At Kota (Rajasthan), Shivran et al., (2013) reported significantly higher grain and stover yield of maize with increasing levels of sulphur application up to $60 \mathrm{~kg} \mathrm{~S} \mathrm{ha}^{-1}$. Dibaba et al., (2014) carried out field experiment at Dharwad, reported that among sulphur levels, application of $40 \mathrm{~kg} \mathrm{ha}^{-1}$ gave the highest grain and stover yield of maize was at par with 30 $\mathrm{kg} \mathrm{ha}^{-1}$ and significantly superior to $20 \mathrm{~kg} \mathrm{~S}$ $\mathrm{ha}^{-1}$. Kumar et al., (2016) reported that application of $50 \mathrm{~kg} \mathrm{~S} \mathrm{ha}^{-1}$, being at par with $25 \mathrm{~kg} \mathrm{~S} / \mathrm{ha}$, significantly enhanced the baby cob and baby corn yield by 17.1 and $22.8 \%$, respectively, over control.

\section{Nutrient contents and their uptake}

Sinha et al., (1995) noticed that uptake of $\mathrm{P}$, $\mathrm{S}, \mathrm{Zn}$ and $\mathrm{Fe}$ in grain and stover of maize increased significantly with increasing levels of sulphur application up to $40 \mathrm{~kg} \mathrm{~S} \mathrm{ha}{ }^{-1}$. Similarly, total N, K and S uptake increased progressively in maize due to increasing levels of sulphur application up to $40 \mathrm{~kg} \mathrm{~S} h a^{-1}$ (Sakalet al., 2000).Majumdar et al., (2002) reported significantly higher sulphur uptake of maize with increasing levels of sulphur application up to $20 \mathrm{~kg} \mathrm{~S}$ ha $^{-1}$. However, Dwivedi et al., (2002) noticed that total S uptake in maize increased significantly with increasing levels of sulphur up to $45 \mathrm{~kg} \mathrm{ha}^{-1}$. Total uptake of $\mathrm{N}, \mathrm{P}$ and $\mathrm{S}$ in maize significantly increased with increasing levels 
of sulphur application up to $60 \mathrm{~kg} \mathrm{ha}^{-1}$ (Mehta et al., 2005). However, Khan et al., (2006) reported that sulphur content in maize leaves increased significantly with increasing levels of sulphur up to $120 \mathrm{~kg} \mathrm{ha}^{-1}$. Total uptake of $\mathrm{N}$ and $S$ in maize grain and stalk increased significantly with increasing levels of sulphur up to $45 \mathrm{~kg} \mathrm{~S} h a^{-1}$ (Bharathi and Poongothai 2008). Srinivasarao et al., (2010) significantly higher sulphur uptake with increasing levels of sulphur application up to $20 \mathrm{~kg} \mathrm{~S} \mathrm{ha}{ }^{-1}$. Application of increasing levels of sulphur up to $15 \mathrm{~kg} \mathrm{~S} h a^{-1}$ produced significantly higher $\mathrm{N}$ content in flag leaves of maize (Jaliya et al., 2012). Jeet et al., (2012) noticed that application of $45 \mathrm{~kg} \mathrm{~S} \mathrm{ha}{ }^{-1}$ significantly increased $\mathrm{N}, \mathrm{P}, \mathrm{K}$ and $\mathrm{S}$ content over $15 \mathrm{~kg} \mathrm{~S}$ $\mathrm{ha}^{-1}$ but it remained at par with $30 \mathrm{~kg} \mathrm{~S} \mathrm{ha}^{-1}$.

\section{Quality}

Sakal et al., (2000) noticed that crude protein content in maize increased from 9.2 to $10.7 \%$ with increasing levels of sulphur application up to $40 \mathrm{~kg} \mathrm{~S} \mathrm{ha}^{-1}$. However, Majumdar et al., (2002) and Rasheed et al., (2004) reported significant increase in maize grain protein content with increasing levels of sulphur application up to $20 \mathrm{~kg}$ of S ha ${ }^{-1}$.Dadhich and Gupta (2005) noticed that application of $40 \mathrm{~kg}$ $\mathrm{S} \mathrm{ha}{ }^{-1}$ to pearlmillet significantly higher crude protein over control but it remained at par with $60 \mathrm{~kg} \mathrm{~S} \mathrm{ha}{ }^{-1}$. However, carbohydrate, starch and protein content in maize increased significantly with increasing levels of sulphur up to $60 \mathrm{~kg} \mathrm{~S} \mathrm{ha}^{-1}$ (Mehta et al., 2005). Similarly, significantly higher carbohydrate, starch and protein yield were observed with increasing levels of sulphur up to $60 \mathrm{~kg} \mathrm{~S} \mathrm{ha}^{-1}$ (Ram et al., 2006). According to Srinivasarao et al., (2010) increasing levels of sulphur application up to $20 \mathrm{~kg} \mathrm{~S}$ ha $^{-1}$ significantly increased crude protein content in maize. Similarly, Jeet et al., (2012) working on quality protein maize noticed significantly higher protein content at $45 \mathrm{~kg} \mathrm{~S} \mathrm{ha}^{-1}$ but on par with $30 \mathrm{~kg} \mathrm{~S} \mathrm{ha}^{-1}$.

\section{Economics}

Application of increasing levels of sulphur from $20-40 \mathrm{~kg} \mathrm{~S} \mathrm{ha}^{-1}$ recorded significantly higher net returns in maize (Patel et al.,2004). Maurya et al., (2005) noticed that increasing levels of sulphur application up to $45 \mathrm{~kg} \mathrm{~S}$ ha ${ }^{1}$ recorded significantly higher net return and B: $C$ ratio in maize. Similarly, application of increasing levels of sulphur up to $60 \mathrm{~kg} \mathrm{~S} \mathrm{ha}^{-1}$ recorded significantly higher gross, net return and B: $C$ ratio in maize ( $R$ am et al., 2006).In four years study at Kanpur (UP) on maize, Srinivasarao et al., (2010) noticed increasing levels of sulphur application up to $20 \mathrm{~kg} \mathrm{~S} \mathrm{ha}^{-}$ ${ }^{1}$ significantly increased net return and B: C ratio. Jeet et al., (2012) reported that application of increasing levels of sulphur up to $45 \mathrm{~kg} \mathrm{~S} \mathrm{ha}{ }^{-1}$ to quality protein maize significantly increased net return and $\mathrm{B}$ : C ratio. While working on baby corn Kumar et $a l$. , (2015a) reported that among the levels of sulphur, gross returns, net returns, B:C ratio were increased correspondingly with each increment of S level up to $50 \mathrm{~kg} \mathrm{~S} \mathrm{ha}^{-1}$ but on par with $25 \mathrm{~kg} \mathrm{~S} \mathrm{ha}^{-1}$.

\section{Soil health}

Jeet et al., (2012) reported significantly higher available $\mathrm{N}$ P, K and $\mathrm{S}$ status in soil with increasing levels of sulphur application up to $45 \mathrm{~kg} \mathrm{~S} \mathrm{ha}^{-1}$.

\section{Effect of zinc}

Zinc is essential for several enzymes that regulate various metabolic activities in plants. It is also vital for oxidation processes in plant cells and helps in transformation of carbohydrates and sugar in plants; enhances cell division and elongation; plays an important role in photosynthesis and nitrogen metabolism which ultimately increased the growth of the maize. Review regarding this nutrient has cited in this section. 


\section{Growth characters}

Leite et al., (2003) conducted a greenhouse experiment to determine the critical levels of zinc on maize and noticed application of increasing levels of zinc up to $32 \mathrm{mg} \mathrm{Zn} \mathrm{kg}^{-1}$ significantly increased dry matter production. Similarly, Adiloglu (2007) revealed that increasing levels of zinc application up to 10 $\mathrm{kg} \mathrm{Zn} \mathrm{ha}{ }^{-1}$ significantly increased dry matter production of maize. Working on pearlmillet, Jakhar et al., (2006) noticed significantly taller plants with increasing levels of zinc application up to $10 \mathrm{~kg} \mathrm{Zn} \mathrm{ha}{ }^{-1}$, which remained at par with $5 \mathrm{~kg} \mathrm{Zn} \mathrm{ha}{ }^{-1}$. According to Sarwar et al., (2012) increasing levels of zinc application up to $8 \mathrm{~kg} \mathrm{Zn} \mathrm{ha}{ }^{-1}$ significantly increased leaf area index. Raskar et al., (2012) conducted an field experiment at at Vadodara (Gujarat) reported that plant height significantly higher in $5 \mathrm{~kg} \mathrm{Zn} \mathrm{ha}^{-1}$ as compared to control. Working at Shalimar (JK), Mahdi et al., (2012) reported significantly taller plants and higher leaf area index of fodder maize with increasing levels of zinc application up to $10 \mathrm{~kg} \mathrm{Zn} \mathrm{ha}{ }^{-1}$. A field experiment conducted at Udaipur, Rajasthan during kharif season 2011 by Meena et al., (2013) to assess the response of different zinc levels $\left(2.5,5.0\right.$ and $\left.7.5 \mathrm{~kg} \mathrm{ha}^{-1}\right)$ to maize cv. PEHM-2 on sandy clay loam soil revealed that application of $5 \mathrm{~kg} \mathrm{Zn} \mathrm{ha}{ }^{-1}$ produced significantly taller plants and dry matter plant ${ }^{-1}$ than $2.5 \mathrm{~kg} \mathrm{Zn} \mathrm{ha}{ }^{-1}$ but it remained at par with $7.5 \mathrm{~kg} \mathrm{Zn} \mathrm{ha}{ }^{-1}$.Azab (2015) reported that combined application of $\mathrm{Zn}(2 \%)$ and NPK fertilizer significantly increased the plant height, leaf area, fresh weigh and dry weight of corn as compared to the treatment fertilized only with NPK. Amanullah et al., (2016) conducted a field experiment at Peshawar, Pakistan for two years in summer and results reveals that the maximum plant height, mean single leaf area and LAI were obtained with $0.2 \% \mathrm{Zn}$. Kumar et al., (2016c) noticed each successive level of zinc application up to $10 \mathrm{~kg} \mathrm{Zn} \mathrm{ha}{ }^{-1}$ correspondingly improved root length, root dry weight and root volume at various growth stages.

Figure.1 Effect of NPKSZn application on growth characters of baby corn (Kumar 2013) Yield attributes and yields

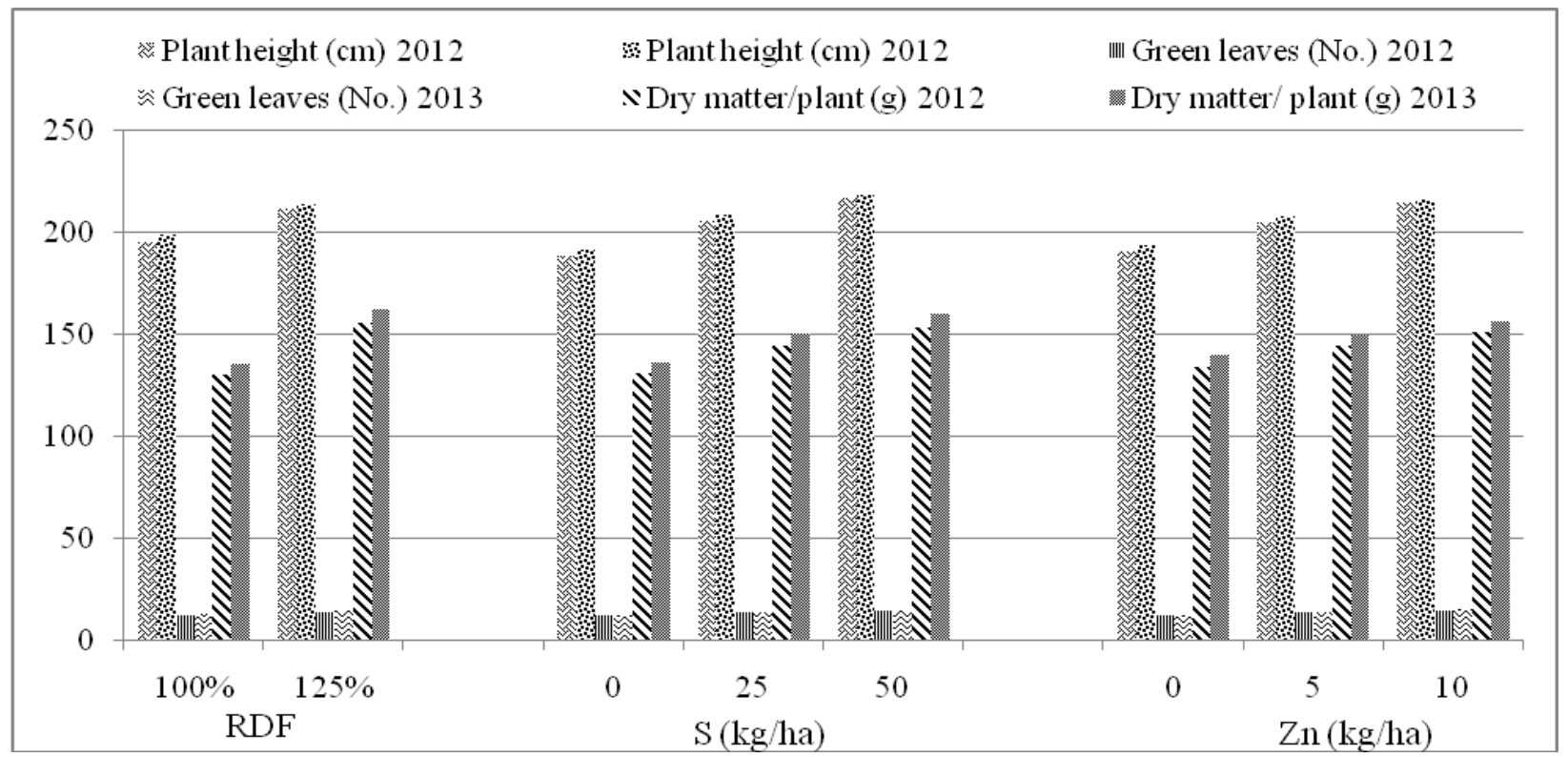


Figure.2 Effect of NPKSZn application on yield attributes of baby corn (Kumar et al 2015a)

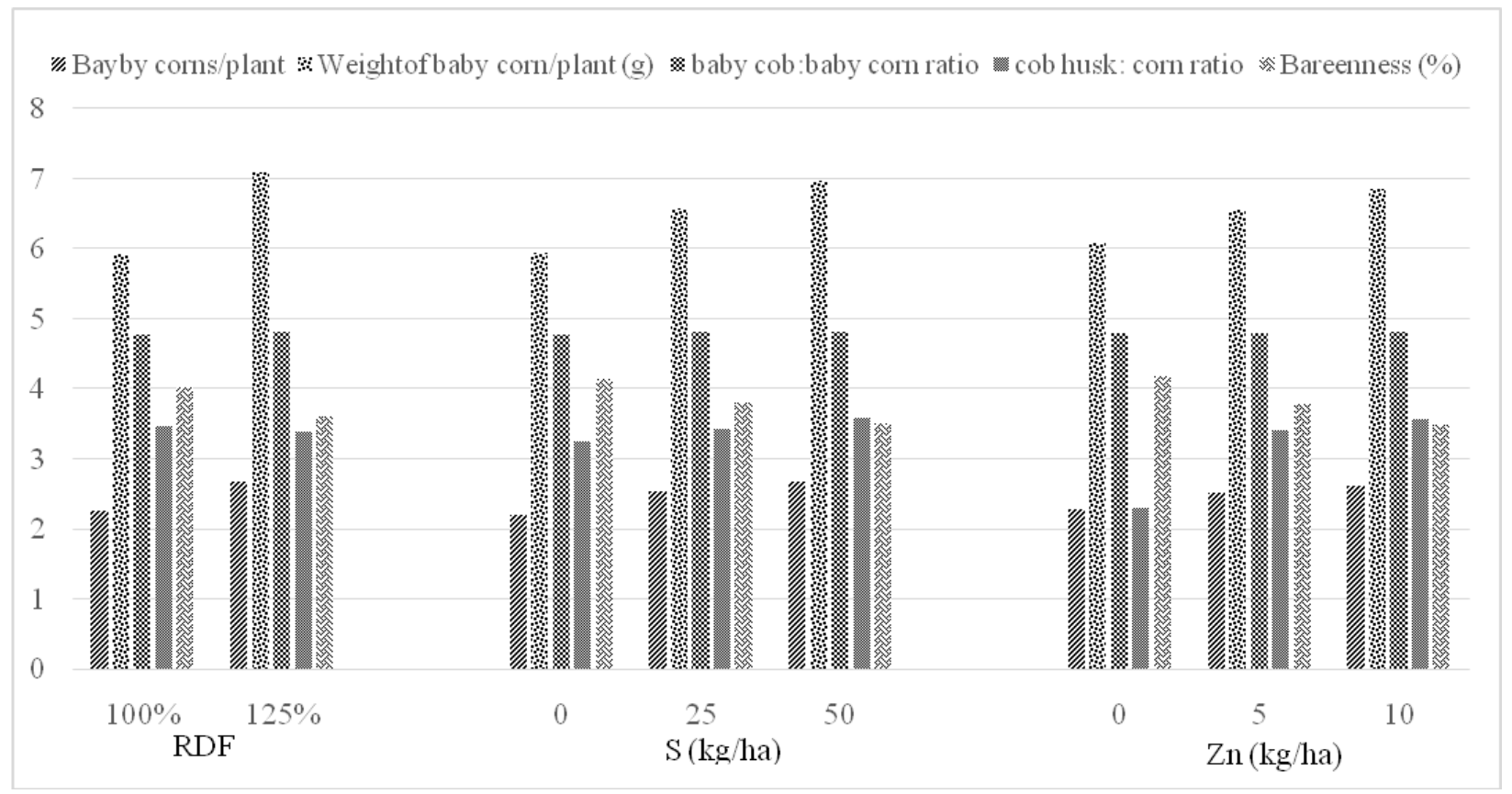

Figure.3 Effect of NPKSZn application on yield of baby corn (Kumar et al 2015a, b, c)

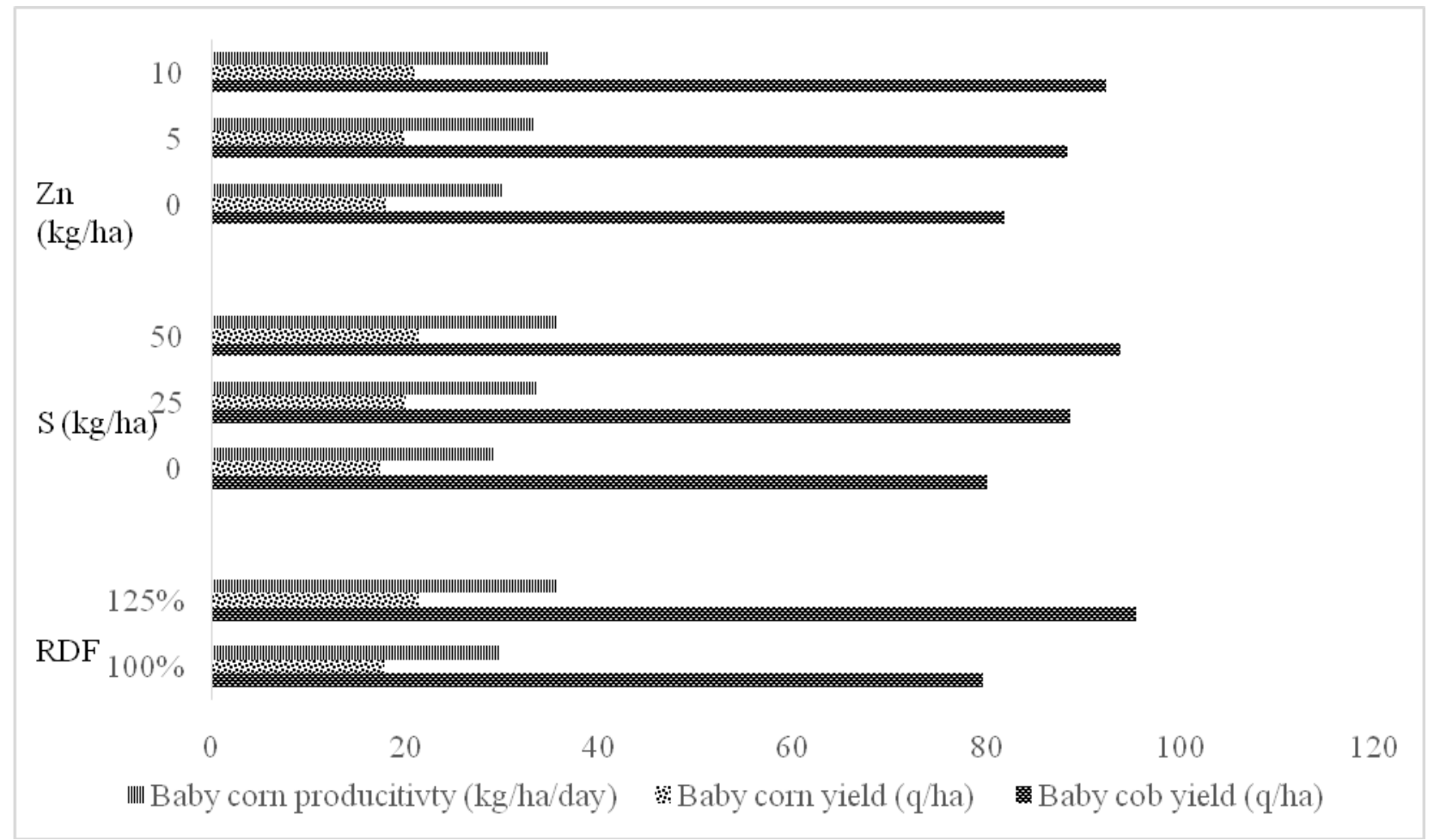


Figure.4 Effect of NPKSZn application on nutrient total uptake by baby corn (Kumar et al., 2015)

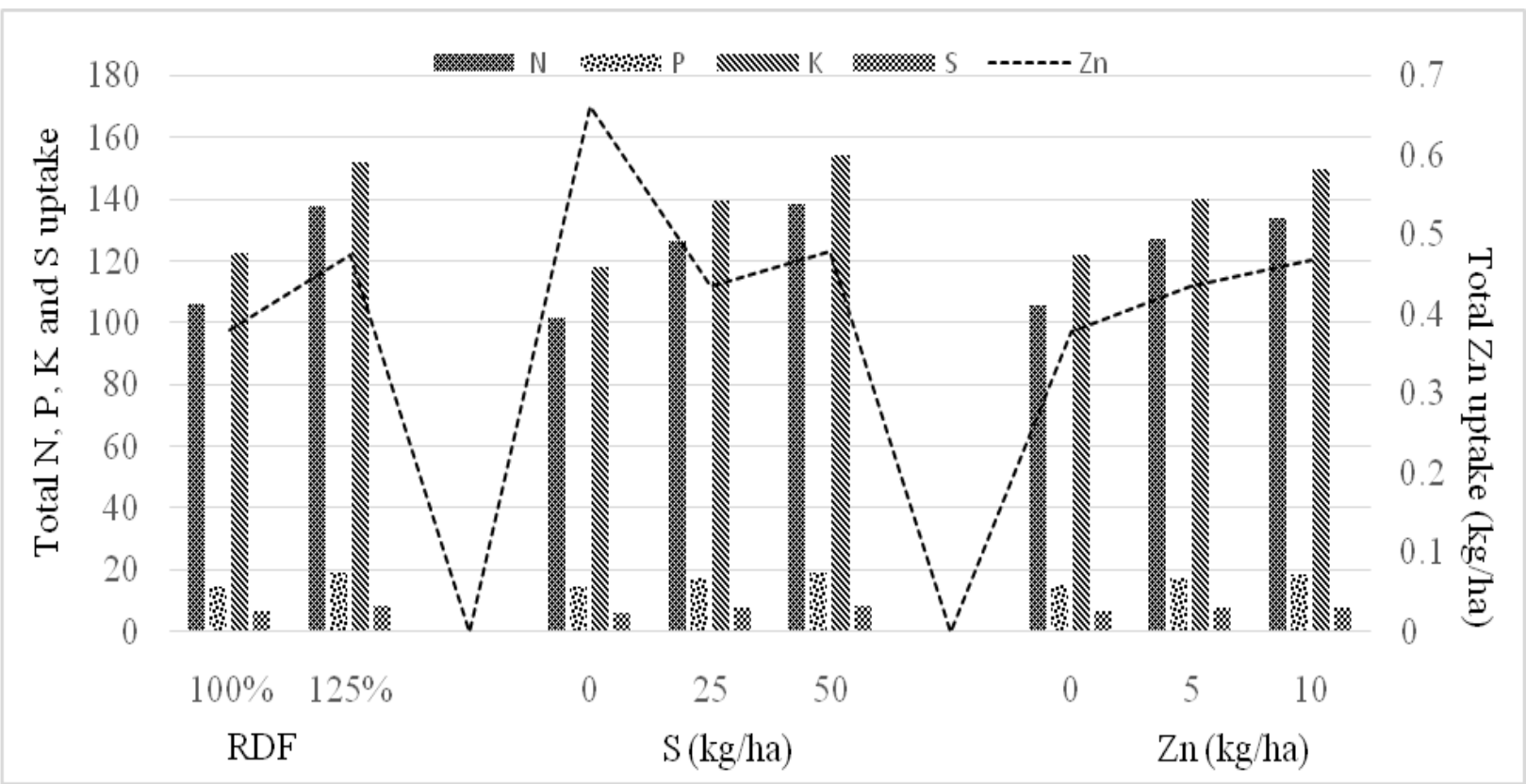

Figure.5 Effect of NPKSZn application on quality parameters of baby corn (Kumar et al 2015b)

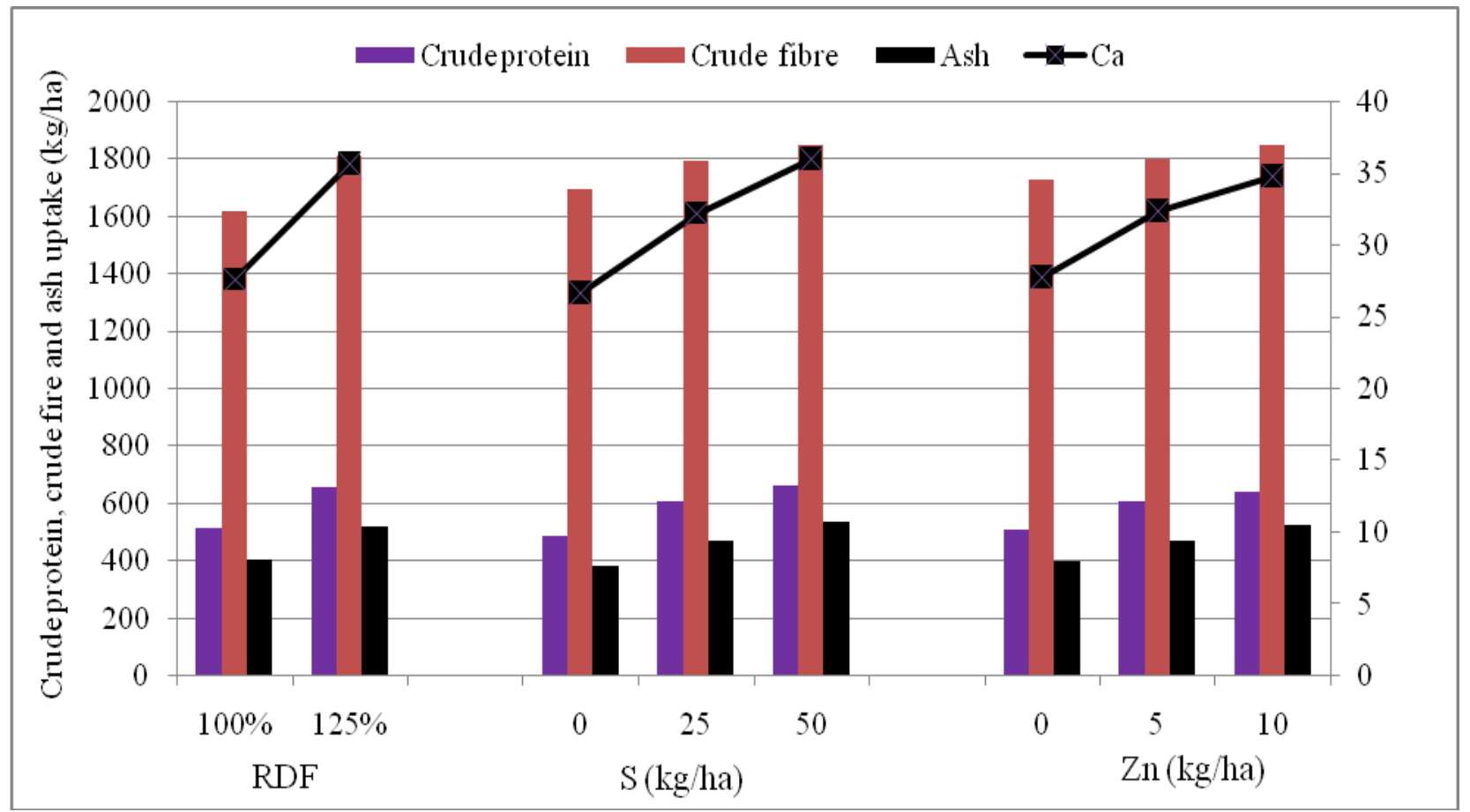


Figure.6 Effect of NPKSZn application on quality parameter of baby corn (Kumar and Bohra 2014)

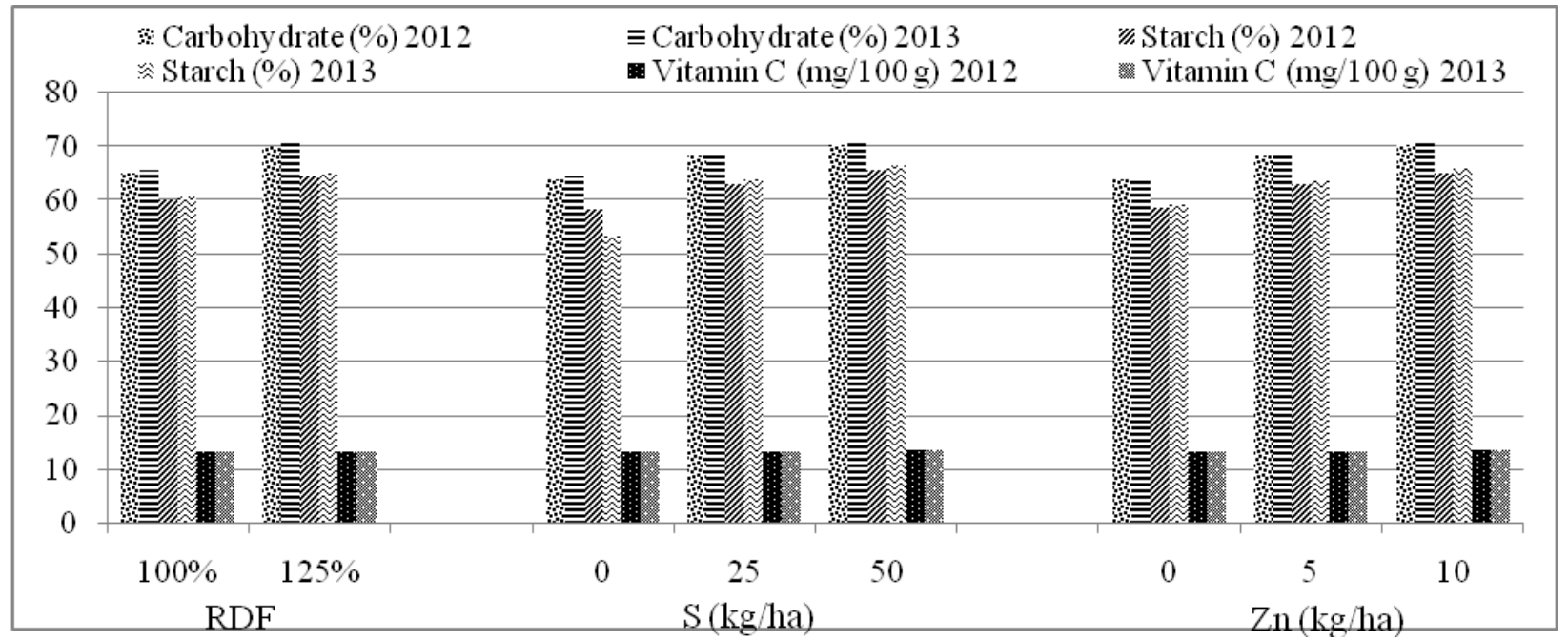

Figure.7 Effect of NPKSZn application on economics of baby corn (Kumar and Bohra 2014)

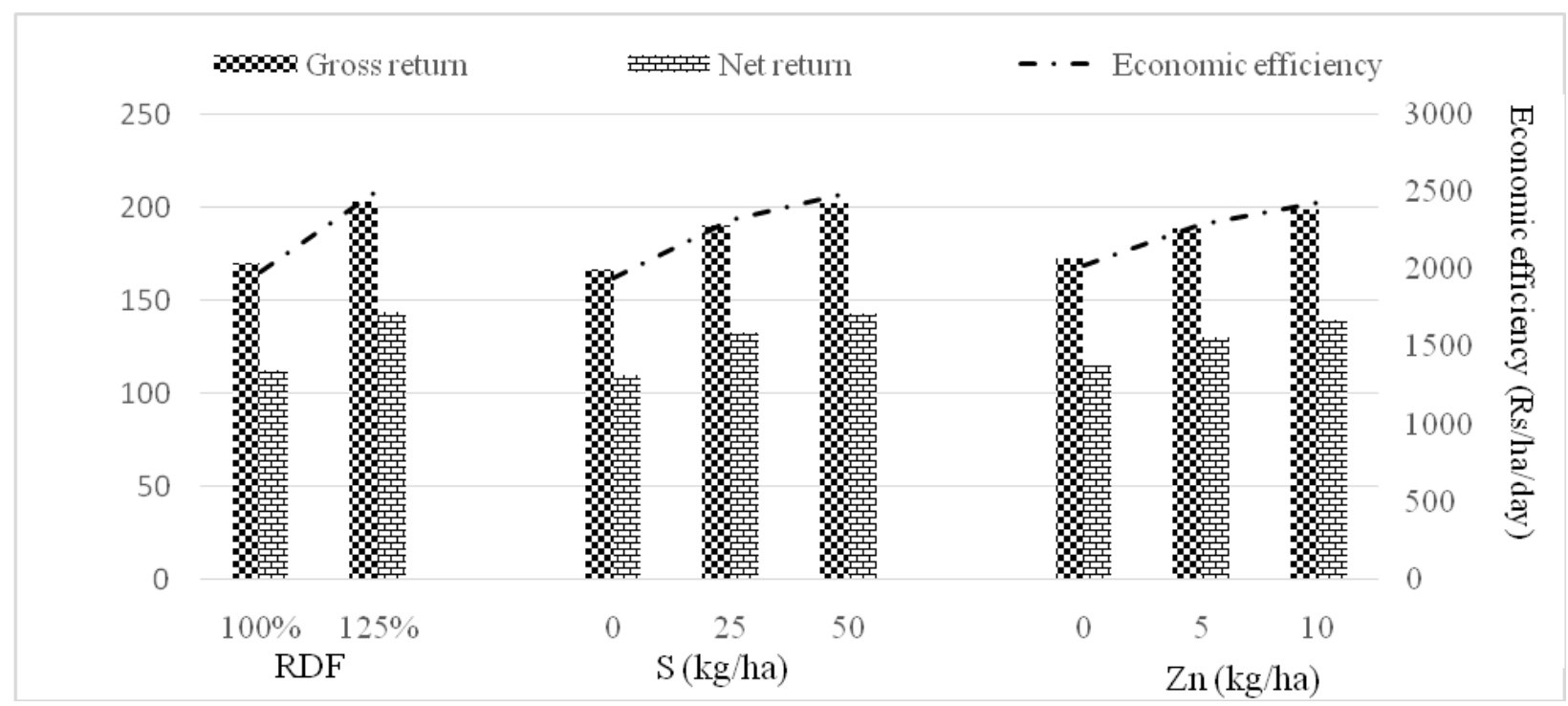

\section{Yield attributes and yields}

Arya and Singh (2000) at New Delhi, studying the response of maize to different levels of zinc application (15 and $30 \mathrm{~kg}$ $\mathrm{ZnSO}_{4} \mathrm{ha}^{-1}$ ) noticed that grain and stover yield increased significantly with increasing levels of zinc application up to $30 \mathrm{~kg} \mathrm{ZnSO}_{4}$ $\mathrm{ha}^{-1}$. Similarly, application of zinc @ $5 \mathrm{~kg} \mathrm{Zn}$ ha $^{-1}$ significantly increased maize yield by
$19 \%$ over control (Dwivedi et al., 2002).Investigating the response of maize to zinc application, Abunyewa and Quarshie (2004) noticed that grain yield increased significantly with application of $5 \mathrm{~kg} \mathrm{Zn} \mathrm{ha}{ }^{-1}$ over control but remained statistically on par with $10 \mathrm{~kg} \mathrm{Zn} \mathrm{ha}{ }^{-1}$. However, percentage increase in maize grain yield due to $\mathrm{Zn}$ application over control ranged from 84$108 \%$. Working at Jobner on pearlmillet, Jain 
and Dahama (2005) reported that increasing levels of zinc application up to $9 \mathrm{~kg} \mathrm{Zn} \mathrm{ha}^{-1}$ correspondingly produced higher grain yield, however there was no significant difference between 6 and $9 \mathrm{~kg} \mathrm{Zn} \mathrm{ha}{ }^{-1}$. Nevertheless, Dadhich and Gupta (2005) reported significantly higher green and dry fodder yield of pearlmillet with increasing levels of zinc application up to $10 \mathrm{~kg} \mathrm{Zn} \mathrm{ha}{ }^{-1}$. Application of $\mathrm{ZnSO}_{4}$ @ $37.5 \quad \mathrm{~kg} \mathrm{ha}^{-1}$ significantly increased grain yield of maize over $12.5 \mathrm{~kg} \mathrm{ZnSO}_{4} \mathrm{ha}^{-1}$ (Shanmugasundaram and Savitri 2005).At Jobner, Jakhar et al., (2006) noticed significantly higher grain and stover yield of pearlmillet with increasing levels of zinc application up to $10 \mathrm{~kg} \mathrm{Zn} \mathrm{ha}{ }^{-1}$. Kakar et al., (2006) reported application of 5 $\mathrm{kg} \mathrm{Zn} \mathrm{ha}{ }^{-1}$ significantly increased 1000-grain weight, cob yield and grain yield of maize over control. Working on maize, at Vidarbha (Maharashtra), Ghodpage et al., (2008) assessed the response of maize to different levels of zinc $\left(0,10\right.$ and $\left.20 \mathrm{~kg} \mathrm{Zn} \mathrm{ha}^{-1}\right)$ and noticed that grain and fodder yield increased significantly with increasing levels of zinc application up to $20 \mathrm{~kg} \mathrm{ha}^{-1}$. Raskar (2012) conducted an field experiment at Vadodara (Gujarat) reported cob length, test weight, no. of grain rows $\mathrm{cob}^{-1}$, shelling percentage and grain yield $\mathrm{cob}^{-1}$ were significantly higher in 5 $\mathrm{kg} \mathrm{Z} \mathrm{ha}{ }^{-1}$ compared to control. It also significantly increased grain and stover yields as compared to control. The per cent increase was to the tune of 10.21 in case of grain and 7.76 in case of stover yield. While working on fodder maize cv. J-1006 at Shalimar (JK), Mahdi et al., (2012) noticed green fodder yield increased significantly with increasing levels of zinc application up to $10 \mathrm{~kg} \mathrm{Zn} \mathrm{ha}^{-1}$. Application of $5 \mathrm{~kg} \mathrm{Zn} \mathrm{ha}{ }^{-1}$ recorded significantly higher grain yield of maize over $2.5 \mathrm{~kg} \mathrm{Zn} \mathrm{ha}^{-1}$ but it remained at par with 7.5 $\mathrm{kg} \mathrm{Zn} \mathrm{ha-1} \mathrm{(Meena} \mathrm{et} \mathrm{al.,} \mathrm{2013).Kumar} \mathrm{and}$ Bohra (2014) observed that application of $125 \% \mathrm{RDF}+10 \mathrm{~kg} \mathrm{Zn}^{-1} \mathrm{ha}$ gave the maximum baby cob (9.24 t/ha), baby corn
(2.1 $\left.\mathrm{t} \mathrm{ha}^{-1}\right)$ and green fodder yield $\left(30.49 \mathrm{t} \mathrm{h}^{-}\right.$ ${ }^{1}$ a) with a net profit $\left(138.81 \times 10^{3} \mathrm{Rs}^{-h^{-1}}\right)$ over control but it remained at par with application of $25 \mathrm{~kg} \mathrm{~S} \mathrm{ha}^{-1}$. Mohsin et al., (2014) results showed that maize hybrid Pioneer 30-Y-87, combined application of $\mathrm{Zn}$ as seed priming $(2 \%)$ and foliar spray (2\%) significantly increased the cob length, cob diameter, 1000grain weight, grain yield, biological yield and harvest index. Azab (2015) reported that combined application of $\mathrm{Zn}(1.5 \%)$ and NPK fertilizer significantly improved cob length, no. of rows, cob girth, 1000-grain weight, grain yield and harvest index as compared to the treatment fertilized only with NPK. Liu et al., (2016) reported that $\mathrm{Zn}$ application of 30 $\mathrm{kg} \mathrm{ZnSO}_{4} \quad 7 \mathrm{H}_{2} \mathrm{O}$ increased grain yield of summer maize. Amanullah et al., (2016) conducted a field experiment at Peshawar, Pakistan for two years in summer growing seasons results reveals that the higher 1000grain weight, Number of grains ear ${ }^{-1}$, grain yield and harvest index were obtained with $0.2 \% \mathrm{Zn}$. Kumar et al., (2015c) found that each successive level of zinc application correspondingly improved the yield of cob and corn up to the highest level and application of 5 and $10 \mathrm{~kg} \mathrm{Zn} \mathrm{ha}^{-1}$ increased cob and corn yield to the tune of $7.8,12.8 \%$ and 10.5 and $16 \%$, respectively, over control.

\section{Nutrient contents and their uptake}

Arya and Singh (2000) noticed that application of $30 \mathrm{~kg} \mathrm{ZnSO} \mathrm{Zha}^{-1}$ significantly increased $\mathrm{Zn}$ uptake in grain and straw of maize over $15 \mathrm{~kg} \mathrm{ZnSO}_{4} \mathrm{ha}^{-1}$. Similarly, Dwivedi et al., (2002) reported uptake of zinc in maize significantly increased with increasing levels of zinc application up to 10 $\mathrm{kg} \mathrm{Zn} \mathrm{ha}{ }^{-1}$. Adiloglu and Saglam (2005) recorded $\mathrm{Zn}$ contents of maize grain significantly increased with increasing doses of $\mathrm{Zn}$ up to $20 \mathrm{mg} \mathrm{kg}^{-1}$. Jain and Dahama (2005) noticed that N, P, K, S and Zn contents and uptake in maize were significantly higher 
at $9 \mathrm{~kg} \mathrm{Zn} \mathrm{ha}{ }^{-1}$ over $3 \mathrm{~kg} \mathrm{Zn} \mathrm{ha}^{-1}$ but the differences between 6 and $9 \mathrm{~kg} \mathrm{Zn} \mathrm{ha}^{-1}$ were not significant. Ghodpage et al., (2008) noticed that $\mathrm{N}, \mathrm{P}$ and $\mathrm{Zn}$ content of maize increased significantly with increasing levels of zinc application up to $20 \mathrm{~kg} \mathrm{Zn} \mathrm{ha}{ }^{-1}$. However, Mahdi et al., (2012) working at Shalimar, (JK) reported that increasing levels of zinc application up to $10 \mathrm{~kg} \mathrm{Zn} \mathrm{ha}{ }^{-1}$ significantly enhanced $\mathrm{N}$ and $\mathrm{Zn}$ content and uptake in fodder maize. Meena et al., (2013) noticed that zinc uptake by maize grain significantly varied with each increment of zinc up to $7.5 \mathrm{~kg} \mathrm{Zn} \mathrm{ha}{ }^{-1}$. While working on maize Mohsin et al., (2014) reported that combined application of $\mathrm{Zn}$ as seed priming $(2 \%)$ and foliar spray (2\%) produced significantly improved zinc content in grain. Azab (2015) reported combined application of $\mathrm{Zn}(1.5 \%)$ and NPK fertilizer significantly improved $\mathrm{N}, \mathrm{P}, \mathrm{K}, \mathrm{Cu}, \mathrm{Fe}, \mathrm{Mn}$ and $\mathrm{Zn}$ content in grain and $\mathrm{N}, \mathrm{P}$ and $\mathrm{K}$ uptake as compared to the treatment fertilized only with NPK. Liu et al., (2016) reported that $\mathrm{Zn}$ application of $30 \mathrm{~kg} \mathrm{ZnSO}_{4} .7 \mathrm{H}_{2} \mathrm{O}$ increased chlorophyll content in leaves and photosynthesis of summer maize.

\section{Quality}

Arya and Singh (2000) noticed increasing levels of zinc application up to $30 \mathrm{~kg} \mathrm{ZnSO}$ $\mathrm{ha}^{-1}$ significantly increased grain protein yield in maize. Similarly, application of increasing levels of zinc application up to $10 \mathrm{~kg} \mathrm{Zn} \mathrm{ha}{ }^{-1}$ significantly improved crude protein content in pearlmillet (Dadhich and Gupta 2005). Mahdi et al., (2012) reported that increasing levels of zinc application up to $10 \mathrm{~kg} \mathrm{Zn} \mathrm{ha}{ }^{-1}$ significantly enhanced crude protein content and protein yield of forage maize.

\section{Economics}

Working on fodder maize at Shalimar, Mahdi et al., (2012) reported that increasing levels of zinc application up to $10 \mathrm{~kg} \mathrm{Zn} \mathrm{ha}^{-1}$ registered significantly higher net return and B: C ratio. Similarly, working at Udaipur (Rajasthan), Meena et al., (2013) reported that application of $10 \mathrm{~kg} \mathrm{Zn} \mathrm{ha}{ }^{-1}$ had significantly higher net return $\left(19.1 \times 10^{3} \mathrm{Rs}^{-h^{-1}}\right)$ and B:C ratio (2.10) of maize over $2.5 \mathrm{~kg} \mathrm{Zn} \mathrm{ha}^{-1}$ but it remained at par with $5.0 \mathrm{~kg} \mathrm{Zn} \mathrm{ha}{ }^{-1}$. While working on baby corn. Kumar et al., (2015c) application of 5 and $10 \mathrm{~kg} \mathrm{Zn} \mathrm{ha}^{-1}$ though remained comparable registered significantly higher gross returns, net returns and $\mathrm{B}: \mathrm{C}$ ratio.

\section{Soil health}

A field experiment was conducted on maize, at Coimbatore by Latha et al., (2002) and they noticed that application of $25 \mathrm{~kg} \mathrm{ZnSO} \mathrm{Zha}^{-1}$ significantly increased the available $\mathrm{Zn}$ status in soil over $12.5 \mathrm{~kg} \mathrm{ZnSO}_{4} \mathrm{ha}^{-1}$. Similarly, Abunyewa and Quarshie (2004) reported available zinc status of soil improved significantly with increasing levels of zinc up to $10 \mathrm{~kg} \mathrm{Zn} \mathrm{ha}^{-1}$ after crop harvest.

\section{Effect of $\mathbf{N}$ and $\mathbf{P}$}

\section{Growth characters}

In a field experiment in Nigeria, Hussaini et al., (2001) evaluated response of maize to different levels of nitrogen $(0,60,120$ and $\left.180 \mathrm{~kg} \mathrm{~N} \mathrm{ha}^{-1}\right)$ and phosphorus ( 0 and $20 \mathrm{~kg} \mathrm{P}$ $\left.\mathrm{ha}^{-1}\right)$. They observed that plant height, dry matter plant ${ }^{-1}$, LAI and crop growth rate were increased significantly with increasing levels of nitrogen and phosphorus up to the highest level. At Bahawalpur (Pakistan), Nazakat et al., (2004) evaluated the effect of combined application of $\mathrm{N}$ and $\mathrm{P}$ i.e. 60-40, 120-50,18060 and 240-70 kg ha ${ }^{-1}$ noticed marked increase in plant height up to $240 \mathrm{~kg} \mathrm{~N}+70$ $\mathrm{kg} \mathrm{P} \mathrm{ha}^{-1}$ over control. Similarly at Anand, Chauhan (2010) evaluating the effect of nitrogen and phosphorus levels $(0,40,80,120$ and $180 \mathrm{~kg} \mathrm{~N} \mathrm{ha}^{-1}$ and 0 and $50 \mathrm{~kg} \mathrm{P}_{2} \mathrm{O}_{5} \mathrm{ha}^{-1}$ ) on sweet corn noticed significantly taller plants with application of increasing levels of 
$\mathrm{N}$ and $\mathrm{P}$ up to $120 \mathrm{~kg} \mathrm{~N} h a^{-1}$ and $50 \mathrm{~kg} \mathrm{P}_{2} \mathrm{O}_{5}$ $\mathrm{ha}^{-1}$.At Udaipur, a two years field experiment on maize was conducted with varying levels of fertility and the results indicated that application of $125 \%$ RDF significantly increased plant height and leaf area index than $75 \%$ RDF but remained comparable with $100 \% \mathrm{RDF}\left(90 \mathrm{~kg} \mathrm{~N}+40 \mathrm{~kg} \mathrm{P}_{2} \mathrm{O}_{5}\right)$. However, highest dry matter and crop growth rate were recorded with $125 \%$ RDF, which proved significantly superior over $100 \%$ and lower levels (Singh and Nepalia 2009).In Nigeria, Onasanya et al., (2009) assessed the effect of different rates of $\mathrm{N}$ and $\mathrm{P}$ fertilization in maize and noticed that plant height, leaves plant $^{-1}$ and leaf area were increased significantly with application of $120 \mathrm{~kg} \mathrm{~N}+0$ $\mathrm{kg} \mathrm{P} \mathrm{ha}{ }^{-1}$ but it remained at par with $60 \mathrm{~kg} \mathrm{~N}$ $+40 \mathrm{~kg} \mathrm{P} \mathrm{ha}{ }^{-1}$. However, stem girth recorded maximum with $60 \mathrm{~kg} \mathrm{~N}+40 \mathrm{~kg} \mathrm{Pha}^{-1}$.

\section{Yield attributes and yields}

Hussaini et al., (2001) carrying out a field study at Savana region of Nigeria to evaluate the response of levels of nitrogen $(0,60,120$ and $180 \mathrm{~kg} \mathrm{~N} \mathrm{ha}^{-1}$ ) to maize and phosphorus $\left(0,20,40 \mathrm{~kg} \mathrm{P} \mathrm{ha}^{-1}\right)$ reported that plant height, dry matter plant ${ }^{-1}$, leaf area index and crop growth rate were significantly increased with increasing levels of nitrogen fertilization up to $180 \mathrm{~kg} \mathrm{~N} \mathrm{ha}{ }^{-1}$, while the effect of phosphorus was not pronounced. At Hyderabad, Yakadri et al., (2001) working on maize cv. IMH-660 noticed that application of $100 \mathrm{~kg} \mathrm{~N}+40 / 60 \mathrm{~kg}$ $\mathrm{P} \mathrm{ha}{ }^{-1}$ significantly improved test weight and grain yield over $80 \mathrm{~kg} \mathrm{~N}+60 \mathrm{P}_{2} \mathrm{O}_{5}$ and $80 \mathrm{~kg}$ $\mathrm{N}+40 \mathrm{~kg} \mathrm{P} \mathrm{O}_{5} \mathrm{O}_{5}{ }^{-1}$.In Pakistan Masood et al., (2003) investigated the performance of maize under different N-P levels and noticed that application of increasing levels of N-P up to $120 \mathrm{~kg} \mathrm{~N}+60 \mathrm{~kg} \quad \mathrm{P} \quad \mathrm{ha}^{-1}$ produced significantly higher grain and stover yield. Similarly, according to Nazakat et al., (2004) application of $180 \mathrm{~kg} \mathrm{~N}+60 \mathrm{~kg} \mathrm{P} \mathrm{ha}{ }^{-1}$ resulted in significantly higher cob length and grain yield of maize but the maximum 1000- grain weight was recorded with $120 \mathrm{~kg} \mathrm{~N}+50$ $\mathrm{kg} \mathrm{P} \mathrm{ha}{ }^{-1}$. Sadiq et al., (2005) while working on maize noticed that application of highest level of N-P i.e. $180-90 \mathrm{~kg} \mathrm{ha}^{-1}$ significantly increased cobs plant ${ }^{-1}$, test weight and grain yield over $120-60 \mathrm{~kg} \mathrm{~N}-\mathrm{P} \mathrm{ha}{ }^{-1}$. At Peshawar (Pakistan), Amin et al., (2006) evaluated the response of sweet corn to N-P levels and noticed significant increase in grain yield with increasing level of N-P up to $300-150 \mathrm{~kg} \mathrm{ha}^{-1}$. While determining the response of maize to different levels of nitrogen $(0,41$ and $64 \mathrm{~kg} \mathrm{~N}$ $\left.\mathrm{ha}^{-1}\right)$ and $\mathrm{P}\left(0,46\right.$ and $\left.69 \mathrm{~kg} \mathrm{P}_{2} \mathrm{O}_{5} \mathrm{ha}^{-1}\right)$, Abudulahi et al., (2006) reported significantly higher grain yield with application of $64 \mathrm{~kg} \mathrm{~N}$ and $46 \mathrm{~kg} \mathrm{P}_{2} \mathrm{O}_{5} \mathrm{ha}^{-1}$. Singh and Singh (2006) at Udaipur (Rajasthan) noticed that yield components of maize viz. cobs plant ${ }^{-1}$ and grains $\mathrm{cob}^{-1}$ significantly increased by 18.8 and $4.3 \%$, respectively with $125 \%$ RDF over $100 \% \operatorname{RDF}\left(90 \mathrm{~kg} \mathrm{~N}+40 \mathrm{~kg} \mathrm{P}_{2} \mathrm{O}_{5} \mathrm{ha}^{-1}\right)$. At Udaipur (Rajasthan) working on popcorn $\mathrm{cv}$. VL Amber, Singh and Choudhary (2008) noticed significantly improved grains $\mathrm{cob}^{-1}$, grain yield and stover yield with the application of $90 \mathrm{~kg} \mathrm{~N}+45 \mathrm{~kg} \mathrm{P}_{2} \mathrm{O}_{5} \mathrm{~kg} \mathrm{ha}^{-1}$ over $60 \mathrm{~kg} \mathrm{~N}+30 \mathrm{~kg} \mathrm{P}_{2} \mathrm{O}_{5} \mathrm{ha}^{-1}$. Working on maize, Singh and Nepalia (2009) reported significant improvement in cobs plant $^{-1}$ and cob length with application of $125 \%$ RDF over $75 \% \mathrm{RDF}$ but it remained at par with $100 \% \mathrm{RDF}$ (90 kg N+40 kg $\left.\mathrm{P}_{2} \mathrm{O}_{5} \mathrm{ha}\right)$. They also noticed significantly higher grains $\mathrm{cob}^{-1}$, grain yield and stover yield of maize with increasing fertility levels up to $125 \%$ RDF. Chauhan (2010) reported significant increase in grain yield of sweet corn with each successive increment of $\mathrm{N}$ and $\mathrm{P}$ level up to $160 \mathrm{~kg} \mathrm{~N}$ and $50 \mathrm{~kg} \mathrm{P}_{2} \mathrm{O}_{5} \mathrm{ha}^{-1}$.

\section{Nutrient contents and their uptake}

Abudulahi et al., (2006) noted that $\mathrm{N}$ and $\mathrm{P}$ contents and their uptake by grain of maize increased significantly with application of 64 $\mathrm{kg} \mathrm{N}$ and $69 \mathrm{~kg} \mathrm{P}_{2} \mathrm{O}_{5} \mathrm{ha}^{-1}$. 


\section{Economics}

Application of $120 \mathrm{~kg} \mathrm{~N}+26.2 \mathrm{~kg} \mathrm{P}+50 \mathrm{~kg}$ $\mathrm{K} \mathrm{ha}{ }^{-1}$ to baby corn brought significantly higher net profit over $100 \mathrm{~kg} \mathrm{~N}+21.8 \mathrm{~kg} \mathrm{P}+$ $41.7 \mathrm{~kg} \mathrm{~K} \mathrm{ha}^{-1}$ and lower doses (Sahoo and Panda 1997). Singh and Choudhary (2008) obtained significantly higher net return $\mathrm{ha}^{-1}$ of Rs. 30,101 ha ${ }^{-1}$ with application of $120 \mathrm{~N} \mathrm{~kg}$ $+60 \mathrm{~kg} \mathrm{P}_{2} \mathrm{O}_{5}$ ha $^{-1}$ over control but it remained at par with $90 \mathrm{~N} \mathrm{~kg}+45 \mathrm{~kg} \mathrm{P}_{2} \mathrm{O}_{5}$ ha ${ }^{1}$.Application $120 \mathrm{~kg} \mathrm{~N}^{-1}$ and $50 \mathrm{~kg} \mathrm{P}_{2} \mathrm{O}_{5}$ $\mathrm{ha}^{-1}$ significantly increased net return as compared to control in sweet corn (Chauhan 2010). Increasing levels of fertility up to $125 \% \mathrm{RDF}\left(112.5 \mathrm{~kg} \mathrm{~N}+50 \mathrm{~kg} \mathrm{P}_{2} \mathrm{O}_{5} \mathrm{ha}^{-1}\right)$ gave significantly higher net returns but highest $\mathrm{B}$ : $\mathrm{C}$ ratio was noted with $125 \% \mathrm{RDF}$, which remained at par with $100 \%$ RDF but proved significantly superior to $75 \% \mathrm{RDF}$ (Singh and Nepalia 2009).

\section{Soil health}

According to Singh and Nepalia (2009) application of $125 \%$ RDF (90 kg N+40 kg $\mathrm{P}_{2} \mathrm{O}_{5}$ ) favourably improved soil organic carbon, available $\mathrm{N}$ and $\mathrm{K}$ status over 100 RDF.

\section{Effect of $\mathrm{N}$ and $\mathrm{K}$}

\section{Growth characters}

Nanjudappa et al., (1994) conducted a field experiment at Bangalore during rainy season on sandy loam soil to assess the effect of nitrogen and potassium application on yield of fodder maize cv. African tall and they observed significant increase in dry matter production with each additional dose of nitrogen from $0-225 \mathrm{~kg} \mathrm{~N}^{-1}$ and that of potassium from 0 to $75 \mathrm{~kg} \mathrm{~K} \mathrm{ha}^{-1}$. Similarly, Sofi et al., (2005) found that plant height, leaves plant ${ }^{-1}$ and dry weight plant ${ }^{-1}$ of maize were increased significantly with each increment in $\mathrm{N}$ and $\mathrm{K}$ levels up to $160 \mathrm{~kg} \mathrm{~N}$ and $80 \mathrm{~kg} \mathrm{~K} \mathrm{ha}^{-1}$, respectively.

\section{Yield attributes and yields}

At Allahabad, Sofi et al., (2004) studied the effect of different levels of nitrogen $(0,120$ and $\left.160 \mathrm{~kg} \mathrm{~N} \mathrm{ha}^{-1}\right)$ and potassium (0,40 and $80 \mathrm{~kg} \mathrm{~K} \mathrm{ha}{ }^{-1}$ ) on maize cv. Ganga Safed-2 noticed that cob length, grains $\mathrm{cob}^{-1}$, cob weight as well as grain and stover yield were increased significantly with each increment of $\mathrm{N}$ and $\mathrm{K}$ up to $160 \mathrm{~kg} \mathrm{~N}$ and $80 \mathrm{~kg} \mathrm{~K} \mathrm{ha}^{-1}$. Gul et al., (2009) at Budgam, Kashmir, assessing the effect of NPK levels on rainfed maize revealed that application of 90: $60: 40 \mathrm{~kg} \mathrm{ha}^{-1}$ and 75: 50: $30 \mathrm{NPK} \mathrm{kg} \mathrm{ha}{ }^{-1}$ recorded significantly maximum cob length, number of cobs plant ${ }^{-1}$, number of grains $\mathrm{cob}^{-1}, 100$-seed weight, grain and stover yield over NPK 60: 40: $20 \mathrm{~kg} \mathrm{ha}^{-1}$.

\section{Quality}

Kumar et al., (2007) reported that application of $100 \% \mathrm{RDN}+100 \% \mathrm{RDP}+125 \% \mathrm{RDK}$ significantly increased reducing sugars compared to RDF alone (RDF: $150-75-37.5 \mathrm{~kg}$ NPK ha-1).

\section{Effect of $P$ and $K$}

\section{Yield attributes and yields}

Working on maize, Hussain et al., (2007) at Peshawar (Pakistan) reported application of increasing rates of phosphorus and potassium significantly increased yield attributes viz. ear weight and 1000-grain weight. However, effect of application of potassium on grain yield was non-significant, but it increased significantly with application of phosphorus. A field experiment was conducted at Coimbatore to study the effect of fertilizer levels on maize and it was noticed that application of 250-125-125 kg NPK ha ${ }^{-1}$ gave significantly higher cob length, cob girth, grains row $\mathrm{cob}^{-1}$ and grain yield but it 
remained comparable with $200-100-100 \mathrm{~kg}$ NPK ha ${ }^{-1}$.

The grain yield increase at $250 \mathrm{~N}-125 \mathrm{P}-125$ $\mathrm{K}$ and $200 \mathrm{~N}-100 \mathrm{P}-100 \mathrm{~K} \mathrm{~kg} \mathrm{ha}^{-1}$ was 17.7 and $17.1 \%$, respectively over $150 \mathrm{~N}-75 \mathrm{P}-75$ $\mathrm{K} \mathrm{kg} \mathrm{ha}^{-1}$ (Srikant et al., 2009). In southern Nigeria, a field study was carried out to assess the different rates on nitrogen and phosphorus fertilizers on maize and it was reported that application of $120 \mathrm{~kg} \mathrm{~N}+40 \mathrm{~kg} \mathrm{P} \mathrm{ha}{ }^{-1}$ significantly increased ear length, grains ear ${ }^{-1}$, weight of grains ear ${ }^{-1}$ and grain yield over 120 $\mathrm{kg} \mathrm{N}+0 \mathrm{~kg} \mathrm{P} \mathrm{ha}{ }^{-1}$, whereas ear girth was noted maximum with $120 \mathrm{~kg} \mathrm{~N}+60 \mathrm{~kg} \mathrm{P} \mathrm{ha}^{-1}$ (Onasanya et al., 2009).

A field experiment was conducted on sandy loam soil during pre-kharif season of 2004 and 2005 by Singh et al., (2010) to find out the appropriate fertility level in baby corn cv. PEHM-2 noticed significant reduction in barrenness (\%) with application of increasing levels of fertility up to $180+38.7+74.7 \mathrm{~kg}$ NPK ha ${ }^{-1}$. Further, they noted that application of $180+38.7+74.7 \mathrm{~kg}^{2} \mathrm{NPK} \mathrm{ha}^{-1}$ significantly increased baby cob and baby corn weight plant $^{-1}$, baby corn girth as well as baby cob, baby corn and green fodder yield over $60+12.9+24.9 \mathrm{~kg}$ NPK ha ${ }^{-1}$ but remained comparable with $120+28.5+49.8 \mathrm{~kg} \mathrm{NPK} \mathrm{ha}^{-1}$. Evaluating fertilizer levels on hybrid maize $\mathrm{COH}(\mathrm{M})-5$ at Coimbatore on sandy loam soil Sekar et al., (2012) noticed significantly higher cob length, girth and grain yield with application of 250-125-125 kg NPK ha ${ }^{-1}$ over $150-75-75 \mathrm{~kg} \mathrm{ha}^{-1}$ but it remained comparable with 200-100-100 kg NPK ha ${ }^{-1}$. The grain yield increase with 250-125-125 NPK kg ha-1 and 200-100-100 kg NPK ha ${ }^{-1}$ were 17.2 and $14.6 \%$, respectively over fertilizers level of 150-75-75 kg ha ${ }^{-1}$. At New Delhi Sobhana et al., (2012) working on baby corn cv. HM-4 noticed that days to baby corn initiation reduced with increasing nutrient levels up to $\mathrm{N}_{187.5} \mathrm{P}_{32.75} \mathrm{~K}_{62.5}$ but application of $\mathrm{N}_{187.5} \mathrm{P}_{32.75}$ $\begin{array}{llll}\mathrm{K}_{62.5} \text { and } \mathrm{N}_{150} & \mathrm{P}_{26.2} & \mathrm{~K}_{50} & \text { being at par gave }\end{array}$ significantly higher cobs plant ${ }^{-1}$ as compared to $\mathrm{N}_{112.5} \mathrm{P}_{19.6} \mathrm{~K}_{22.6}$ and control. Cob weight with husk and without husk showed marked improvement with each successive increment in nutrient levels up to $\mathrm{N}_{187.5} \mathrm{P}_{32.75} \mathrm{~K}_{62.5}$. In case of fodder, yield increased with increasing in nutrient levels only up to $\mathrm{N}_{150} \mathrm{P}_{26.2} \mathrm{~K}_{50}$.

Lone et al., (2013) conducted field experiment at Srinagar, Kashmir, Jammu and Kashmir on baby corn, reported that application of $5 \mathrm{t} \mathrm{FYM+150 \%} \mathrm{recommended}$ dose of fertilizer $\left(225 \mathrm{~N}: 90 \mathrm{P}_{2} \mathrm{O}_{5}: 60 \mathrm{~K}_{2} \mathrm{O}\right.$ $\mathrm{kg} \mathrm{ha}^{-1}$ ) revealed maximum no. of cobs plot $^{-1}$, co girth, cob yield (without husk) and green fodder yield. Dibaba et al., (2014) carried out field experiment at Dharwad, reported that among the NPK levels, application of 300:150:75 kg NPK ha- ${ }^{-1}$ produced the highest grain and stover yield and was at par with 225:112.5:56.25 $\mathrm{NPK} \mathrm{ha}^{-1}$.

Kumar et al., (2015) reported that application of $125 \%$ RDF (IN)+25\% RDF (ON) proved the best for getting higher baby corn and fodder productivity under the foot hill condition of Eastern Himalaya, India. While working on sweet corn Rasool et al., (2015) found that application of 75\% NPK + FYM $4.5 \mathrm{t} \mathrm{ha}^{-1}+$ biofertilizer proved to be significantly superior in respect to cob yield with and without husk, fodder yield and green biomass yield over to rest of the treatments including unfertilized control. Kumar et al., (2015c) reported that application of $125 \%$ RDF significantly increased yield of baby cob, baby corn fodder yield over $100 \%$ RDF. The yield differences in baby cob and baby corn were 19.8 and $20.1 \%$, respectively, over $100 \%$ RDF.

\section{Effect of $N, P$ and $K$}

\section{Growth characters}

Working at Bangalore, Kadir (2002) reported that application of $100 \%$ RDF (150-75-50 kg 
NPK ha ${ }^{-1}$ ) significantly enhanced plant height, LAI and total dry matter production of maize over $50 \%$ RDF and lower doses but remained on par with $75 \%$ RDF. Karki et al., (2005) conducting field experiment on sandy soil at IARI New Delhi during rainy season to study the nutrient management in maize var. PEHM-3 reported significantly taller plants and dry matter plant ${ }^{-1}$ at $120 \mathrm{~N}+26.2 \mathrm{P}+$ $41.5 \mathrm{~K} \mathrm{~kg} \mathrm{ha}^{-1}$ over $60 \mathrm{~N}+13.1 \mathrm{P}+20.8 \mathrm{~K}$ $\mathrm{kg} \mathrm{ha}{ }^{-1}$. Sadiq et al., (2005) conducted an experiment to evaluate the effect of graded potassium application rates i.e. 0, 60, 120, 180 and $240 \mathrm{~kg} \mathrm{~K} \mathrm{ha}^{-1}$ on maize hybrid C707, sown at different fertility levels i.e. 0, $100 \%$ recommended dose (RD) of N-P (120$\left.60 \mathrm{~kg} \mathrm{ha}^{-1}\right)$ and $150 \%$ RD of N-P (180-90 kg $\left.\mathrm{ha}^{-1}\right)$. They reported significantly taller plants and delayed silking with application of increasing N-P levels up to $180-90$, N-P kg $\mathrm{ha}^{-1}$. However, potash application at $180 \mathrm{~kg} \mathrm{~K}$ $\mathrm{ha}^{-1}$ produced significantly taller plants but delayed silking over 120 and $240 \mathrm{~kg} \mathrm{~K} \mathrm{ha}^{-1}$. At New Delhi, Kumar et al., (2006) observed that plant height and dry matter production of maize were significantly higher with application of $100 \%$ RDF (160-26.2-33.2 kg NPK ha ${ }^{-1}$ ) over $75 \%$ and $50 \%$ RDF. However, Singh and Singh (2006), evaluating the response of early maturing maize hybrid PEHM-1 and PHEM-2 to fertility levels noticed that application of $125 \%$ RDF recorded significantly taller plants and dry matter production over $100 \%$ RDF $(90,40,40$ $\mathrm{kg}$ NPK ha $\left.{ }^{-1}\right)$. At Bangalore, a field experiment on hybrid maize $\mathrm{NHH}-2049$ with varying fertility levels was carried out during rainy season by Vishalu et al., (2009).They observed that plant height, total dry matter production and net assimilation rate were significantly higher with application of $150 \%$ NPK over 100\% NPK (100\% NPK:100-50-25 $\left.\mathrm{kg} \mathrm{ha}^{-1}\right)$. Similarly, Zende et al., (2009) at Dapoli, studying the nutrient management on sweet corn cv. Sugar 75 revealed that plant height and dry matter plant ${ }^{-1}$ were significantly superior with $150 \%$ RDF over $100 \%$ RDF (225-60-60 kg NPK ha ${ }^{-1}$ ) and lower doses. Sobhana et al., (2012) conducted a field experiment at IARI New Delhi during kharif season of 2010 to assess the nutrient requirements of baby corn hybrid HM-4 and noticed that each increase in NPK level from control to $\mathrm{N}_{187.5} \mathrm{P}_{32.75} \mathrm{~K}_{62.5}$ recorded significantly taller plants and higher dry weight plant $^{-1}$ but LAI improved only up to application of $\mathrm{N}_{150} \quad \mathrm{P}_{26.2} \mathrm{~K}_{50}$. Lone et al., (2013) conducted field experiment at Srinagar, Kashmir, Jammu and Kashmir on baby corn, reported that application of $5 \mathrm{t}$ FYM+ $150 \%$ recommended dose of fertilizer $\left(225 \mathrm{~N}\right.$ : $90 \mathrm{P}_{2} \mathrm{O}_{5}: 60 \mathrm{~kg} \mathrm{~K}_{2} \mathrm{O} \mathrm{ha}{ }^{-1}$ ) produced taller plants as compared to rest of the treatments. At Budgam, Kashmir Gul et al.,(2015) reported that application of NPK 90 : $60: 40 \mathrm{~kg} \mathrm{ha}^{-1}$ and $75: 50: 30 \mathrm{~kg} \mathrm{ha}^{-1}$ both were at par and gave higher plant height, leaf area index, dry matter production at different growth stages of rainfed maize and significantly superior over the level of NPK $60: 40: 20 \mathrm{~kg} \mathrm{ha}^{-1}$.Rasool et al., (2015) observed that $75 \%$ NPK + FYM $4.5 \mathrm{t} \mathrm{ha}^{-1}+$ biofertilizer significantly increased the plant height, leaf area index and dry matter accumulation, number of days taken to tasseling, silking and milky stages as compared to rest of the treatments. Singh et al., (2016b) carried out a field experiment on baby corn and reported that among nutrient management treatments, the integration of $5 \mathrm{t}$ FYM with $100 \mathrm{~kg}$ of inorganic $\mathrm{N} \mathrm{ha}{ }^{-1}$ significantly increased growth characters viz. plant height, number of leaves per plant, leaf area index and dry matter accumulation as compared to rest of the nutrient management treatments. Kumar et al., (2016b) carried out a field experiment at Varanasi (UP) results reveals that application of $125 \%$ RDF significantly increased the root length, root dry weight and root volume of baby corn at respective stage of crop growth over $100 \%$ RDF. 


\section{Yield attributes and yields}

Kadir (2002) reported significantly higher grain $\mathrm{cob}^{-1}$ as well as grain and stover yield of maize with application of $100 \%$ RDF (15075-50 kg NPK ha ${ }^{-1}$ ) over control but remained on par with $75 \%$ RDF. At Bangalore Kataraki et al., (2004) conducted experiment to assess the application of different fertility levels on maize hybrid DMH-2 and noticed significantly higher grain yield with increasing levels of fertility up to $100 \% \mathrm{RDF}$ (150-75-37 kg NPK ha ${ }^{-1}$ ). According to Karki et al., (2005) grain and stover yield of maize were significantly higher with application of $120 \mathrm{~N}+26.2 \mathrm{P}+41.5 \mathrm{~K} \mathrm{~kg} \mathrm{ha}^{-1}$ over $60 \mathrm{~N}+$ $13.1 \mathrm{P}+20.8 \mathrm{~K} \mathrm{~kg} \mathrm{ha}^{-1}$. Similarly, conducting a field experiment on maize at New Delhi on sandy loam, Ahlawat et al., (2005) noticed significant improvement in grain yield with increasing levels of fertility up to $100 \% \mathrm{RDF}$ (120-60-40-5 kg N-P $\mathrm{O}_{5}-\mathrm{K}_{2} \mathrm{O}-\mathrm{Zn} \mathrm{ha}{ }^{-1}$ ). At Kalyani (WB) Saha and Mondal (2006) conducted a field experiment to study the effect of fertility levels on baby corn and stated that application of increasing levels of fertility up to $100 \%$ RDF (150-60-40 kg NPK $\mathrm{ha}^{-1}$ ) significantly improved yield components viz. green cob weight, corn weight and no. of corn plant ${ }^{-1}$ as well as cob, corn yield and green fodder yield but barrenness (\%) decreased with increasing fertility levels and maximum at control. Kumar et al., (2006) working on maize, also reported similar results. Zende et al., (2009) reported that yield attributes and yield of sweet corn were significantly improved with increasing levels of fertility up to $150 \%$ RDF (RDF: 225-60-60 $\left.\mathrm{kg} \mathrm{ha}^{-1}\right)$. According to Vishalu et al.,(2009) yield attributing characters viz. cobs plant ${ }^{-1}$, cob length and girth as well as grain and stover yield of maize increased significantly with increasing fertility levels up to $150 \%$ RDF (100\% RDF: 100-50-25 $\mathrm{kg} \mathrm{ha}^{-1}$ ).

\section{Nutrient contents and their uptake}

Karki et al., (2005) reported significant increase $\mathrm{N}, \mathrm{P}, \mathrm{K}$ and $\mathrm{Zn}$ content as well as uptake in grain and stover of maize with application of $100 \%$ RDF $(120 \mathrm{~kg} \mathrm{~N}+26.2 \mathrm{~kg}$ $\mathrm{P}+41.5 \mathrm{~kg} \mathrm{~K} \mathrm{ha}^{-1}$ ) over $60 \mathrm{~kg} \mathrm{~N}+13.2 \mathrm{~kg} \mathrm{P}$ $+20.8 \mathrm{~kg} \mathrm{~K} \mathrm{ha}{ }^{-1}$ and lower doses. According to Zende et al., 2009, N uptake by corn and fodder of sweet corn increased significantly with $150 \%$ RDF over $100 \%$ RDF but P uptake was maximum at $100 \%$ RDF (225-60$60 \mathrm{~kg}$ NPK ha-1). Kumar and Dhar (2010) reported significant increase in $\mathrm{N}, \mathrm{P}$ and $\mathrm{K}$ uptake by maize with application of $120 \mathrm{~kg} \mathrm{~N}$ $+26 \mathrm{~kg} \mathrm{P}+32 \mathrm{~K} \mathrm{~kg} \mathrm{ha}^{1}{ }^{1}$ over $60 \mathrm{~kg} \mathrm{~N}+13$ $\mathrm{kg} \mathrm{P}+25 \mathrm{~K} \mathrm{~kg} \mathrm{ha-}{ }^{-}$. Similarly, Singh et al., (2010) stated that N, P and K content in baby corn significantly increased with $180+38.7+74.7 \quad \mathrm{~kg} \quad \mathrm{NPK} \mathrm{ha}^{-1}$ than $60+12.9+24.9 \mathrm{~kg}$ NPK $\mathrm{ha}^{-1}$ but remained statistically on par with $120+28.5+49.8 \mathrm{~kg}$ NPK ha ${ }^{-1}$. Sobhana et al., (2012) noticed that $\mathrm{P}$ and $\mathrm{K}$ uptake significantly improved with each increment of NPK level from 0- $\mathrm{N}_{187.5}$ $\mathrm{P}_{32.75} \mathrm{~K}_{62.5}$ in baby corn, husk and fodder.

\section{Quality}

Zende et al., (2009) noted that protein content in grain of sweet corn significantly improved with increasing fertility levels up to $150 \%$ RDF. However, $150 \%$ RDF remained at par with $100 \%$ RDF (225-60-60 kg NPK ha-1). Application of increasing level of nutrients up to $250+125+125 \mathrm{~kg}$ NPK ha ${ }^{-1}$ significantly improved crude protein and starch content in hybrid maize (Sekar et al., 2010).Singh et al., (2010) reported significantly increased protein content, carbohydrate, starch, reducing sugar and non-reducing sugar in baby corn with application of $180+38.7+74.7$ $\mathrm{kg}$ NPK ha ${ }^{-1}$ over $60+12.9+24.9 \mathrm{~kg} \mathrm{NPK} \mathrm{ha}^{-1}$ but remained at par with $120+28.5+49.8 \mathrm{~kg}$ NPK ha ${ }^{-1}$. 


\section{Economics}

While working on maize, Sankaran et al., (2005) noticed that application of increasing levels of fertility up to $150 \%$ RDF $(100 \%$ RDF: $135-62.5-50 \mathrm{~kg}$ NPK $\mathrm{ha}^{-1}$ gave maximum net return and $\mathrm{B}$ : $\mathrm{C}$ ratio. According to Kumar et al., (2006) application of $75 \% \mathrm{RDF}$ to winter maize recorded significantly higher $\mathrm{B}$ : $\mathrm{C}$ ratio over $50 \% \mathrm{RDF}$ but remained at par with $100 \%$ RDF (16026.2-33.2 kg NPK ha $\left.^{-1}\right)$.Similarly, significantly increasing gross, net return and $\mathrm{B}$ : C ratio in sweet corn were noticed with application of increasing levels of fertility up to $100 \%$ RDF (Zende et al., 2009).Sekar et al., (2010) working on hybrid maize reported significantly higher gross and net return with increasing NPK levels up to 250-125-125 kg NPK ha ${ }^{-1}$. Similarly, according to Singh et al., (2010)observed that net return and B:C ratio in baby corn significantly increase with each successive increasing in nutrients level up to $180+38.7+74.7 \mathrm{~kg}$ NPK ha ${ }^{-1}$.Kumar et al., (2016) results reveal that application of $125 \%$ RDF gave significantly higher gross returns, net returns and benefit : cost ratio over $100 \%$ RDF.

\section{Soil health}

Parasuraman (2005) noticed that application of $125 \%$ NPK significantly increased available N, P and $\mathrm{K}$ status in soil over $100 \%$ NPK (135-62.5-50 kg ha ${ }^{-1}$ ). Similarly, Kumar et al., (2006) noted that application of increasing level of fertilizer up to $100 \% \mathrm{RDF}$ (160 N-26.2 P-33.2 $\mathrm{K} \mathrm{kg} \mathrm{ha}^{-1}$ ) significantly increased available $\mathrm{N}, \mathrm{P}$ and $\mathrm{K}$ status in soil over $75 \%$ RDF and lower doses. Whereas, as et al., (2010) noticed significantly higher $\mathrm{N}, \mathrm{P}$ and $\mathrm{K}$ status of soil with increasing fertility levels up to $100 \%$ NPK. Significantly higher available $\mathrm{N}, \mathrm{P}$ and $\mathrm{K}$ status of soil was also noted with increasing fertility levels up to $180+38.7+74.7 \mathrm{~kg}$ NPK ha ${ }^{-1}$ (Singh et al., 2010).

\section{Effect of N, P, K and Zn}

\section{Growth characters}

Ashoka et al., (2009) assessing the effect of macro and micro-nutrient application on baby corn cv. PAC-792 revealed that application of $150-75-45$ kg NPK ha ${ }^{-1}$ (RDF) + $\mathrm{ZnSO}_{4} @ 25$ $\mathrm{kg}$ recorded significantly taller plants, number leaf plant ${ }^{-1}$ and dry matter production plant $^{-1}$ over RDF alone.

\section{Effect of N, P, K, S and Zn}

\section{Yield attributes and yields}

At Rakh Diandar (Jammu) Abrol et al., (2007) reported that application of $100 \%$ RDF (NPK: 60-40-20 kg ha ${ }^{-1}$ ) $+\mathrm{ZnSO}_{4} @ 20 \mathrm{~kg}$ $\mathrm{ha}^{-1}$ significantly increased grain yield of maize to the tune of $120 \%$ over control. Working on baby corn, Ashoka et al., (2009) observed that application of RDF (150-75-45 $\mathrm{kg}$ NPK ha $\left.{ }^{-1}\right)+\mathrm{ZnSO}_{4} @ 25 \mathrm{~kg} \mathrm{ha}^{-1}$ significantly improved corn plant $^{-1}$, corn weight, corn and green fodder yield over RDF alone. At Tuticorin (TN), Paramasivan et al., (2010) worked out nutrient optima for hybrid maize through balanced fertilization and noticed significantly maximum grain yield with increasing level of nutrient up to 250-6448-4.8 kg NPKZn ha ${ }^{-1}$. According to Ashoka and Sunitha (2011) significantly higher baby corn yield was recorded with application of $100 \%$ RDF (150-60-40 kg NPK ha $\left.{ }^{-1}\right)+25 \mathrm{~kg}$ $\mathrm{ZnSO}_{4}$ over RDF (150-60-40 kg NPK ha ${ }^{-1}$ ) alone. A field experiment was conducted at Coimbatore to study the effect of balanced fertilization on maize by Paramasivan et al., (2011), they noticed increasing levels of NPKZn application up to $250+60+25+10 \mathrm{~kg}$ NPKZn ha ${ }^{-1}$ significantly increased cob length and girth, grain and stover yield. At Varanasi, Kumar and Bohra (2014) evaluated the effect of nitrogen, phosphorus and potassium (NPK) $(100 \%$ and $125 \%$ recommended dose of 
fertilizer), sulfur $\left(0,25\right.$ and $\left.50 \mathrm{~kg} \mathrm{~S} h a^{-1}\right)$ and zinc $\left(0,5\right.$ and $\left.10 \mathrm{~kg} \mathrm{Zn} \mathrm{ha}^{-1}\right)$ and found application of $125 \%$ RDF over $100 \%$ RDF resulted in significant growth in green leaves, stem girth, dry matter plant ${ }^{-1}$, crop growth rate (CGR), chlorophyll content of leaves, yield attributes like number of baby cobs plant ${ }^{-1}$, cob and corn weight, length and girth of corn as well as yield of cob, corn and green fodder. Jeet et al., (2014) evaluated the effect of four nitrogen levels $\left(0 \mathrm{~kg} \mathrm{~N} \mathrm{ha}^{-1}, 50 \mathrm{~kg} \mathrm{~N}^{-1}{ }^{-1}, 100\right.$ $\mathrm{kg} \mathrm{N} \mathrm{ha}^{-1}$ and $150 \mathrm{~kg} \mathrm{~N} \mathrm{ha}^{-1}$ ) and three levels of sulphur $\left(15 \mathrm{~kg} \mathrm{Sha}^{-1}, 30 \mathrm{~kg} \mathrm{~S} \mathrm{ha}^{-1}\right.$ and 45 $\left.\mathrm{kg} \mathrm{S} \mathrm{ha}{ }^{-1}\right)$ in quality protein maize (QPM) and observed significantly highest plant height, leaf area index (LAI) and yield were recorded with $150 \mathrm{~kg} \mathrm{~N} \mathrm{ha}^{-1}$ as compared to $\mathrm{N}_{100}, \mathrm{~N}_{50}$ and $\mathrm{N}_{0}$. Kumar (2013) reported that cob, corn and green and dry fodder yield, net profit, nutrient content (NPKSZn) and their uptake were recorded significantly higher with application of $125 \%$ RDF. Further, application of $50 \mathrm{~kg} \mathrm{~S} \mathrm{ha}{ }^{-1}$ resulted in significant increase in cob, corn; green fodder yield, net profit and nutrient content and uptake of baby corn over control but it remained at par with $25 \mathrm{~kg} \mathrm{~S}^{-1}$. Similar trend was also observed with application of $\mathrm{Zn}$ levels. Increasing levels of sulphur and zinc progressively improved fodder quality attributes of baby corn viz., crude protein, ash, $\mathrm{Ca}$ content except crude fibre content which followed reverse trend.Kumar et al., (2015) reported that baby corn and green fodder yields, economics and nutrient uptake (N, P, K, S and Zn) were significantly higher with application of $125 \%$ recommended dose of fertilizer (RDF). Shivran et al., (2013) reported that application of RDF $+60 \mathrm{~kg} \mathrm{Sha}^{-1}$ recorded significantly higher seed, stover and biological yields over control.

\section{Nutrient contents and their uptake}

Application of 250-64-48-4.8 kg NPKZn ha ${ }^{-1}$ significantly improved $\mathrm{N}, \mathrm{P}, \mathrm{K}$ and $\mathrm{Zn}$ uptake over 200-64-60-4.8 kg NPKZn $\mathrm{ha}^{-1}$ (Paramasivan et al., 2010). Similarly, Paramasivan et al., (2011) observed that maize supplied with $250 \mathrm{~kg} \mathrm{~N}+60 \mathrm{~kg} \mathrm{P}_{2} \mathrm{O}_{5}+$ $25 \mathrm{~kg} \mathrm{~K}_{2} \mathrm{O}+10 \mathrm{~kg} \mathrm{Zn} \mathrm{ha}^{-1}$ caused significant enhancement of total $\mathrm{N}$ and $\mathrm{Zn}$ uptake but highest $\mathrm{P}$ and $\mathrm{K}$ uptake were noted with 200 $\mathrm{kg} \mathrm{N}+75 \mathrm{~kg} \mathrm{P}_{2} \mathrm{O}_{5}+25 \mathrm{~kg} \mathrm{~K}_{2} \mathrm{O}+10 \mathrm{~kg} \mathrm{Zn} \mathrm{ha}^{-1}$ followed by $200 \mathrm{~kg} \mathrm{~N}+60 \mathrm{~kg} \mathrm{P}_{2} \mathrm{O}_{5}+31.25 \mathrm{~kg}$ $\mathrm{K}_{2} \mathrm{O}+10 \mathrm{~kg} \mathrm{Zn} \mathrm{ha}^{-1}$. Ashoka and Sunitha (2011) noticed that N, P, K and Zn uptake by baby corn significantly increased with application of $100 \%$ RDF (150-60-40 kg NPK $\left.\mathrm{ha}^{-1}\right)+25 \mathrm{~kg} \mathrm{ZnSO}{ }_{4}$ over $100 \% \mathrm{RDF}$ alone.

\section{Quality}

Application of 150-75-45 kg NPK ha ${ }^{-1}$ (RDF) + $\mathrm{ZnSO}_{4} @ 25 \mathrm{~kg} \mathrm{ha}^{-1}$ significantly increased protein content and reducing sugar in baby corn over RDF alone (Ashoka et al., 2009).

\section{Economics}

Ashoka et al., (2009) noticed that application of 150-75-45 kg NPK ha ${ }^{-1}(\mathrm{RDF})+\mathrm{ZnSO}_{4}$ @ $25 \mathrm{~kg} \mathrm{ha}^{-1}$ registered significantly higher gross return, net return and $\mathrm{B}$ : $\mathrm{C}$ ratio over RDF alone. Application of increasing levels of NPKZn up to $250+60+25+10 \mathrm{~kg}$ NPKZn $\mathrm{ha}^{-1}$ recorded significantly higher net and B: C ratio over 200-60-31.5-10 kg NPKZn ha ${ }^{-1}$, whereas the lowest was recorded under control (Paramasivan et al., 2011). Similarly, significantly higher net return and $\mathrm{B}$ : $\mathrm{C}$ ratio was noted with application of $100 \%$ RDF (150-60-40 kg NPK ha $\left.{ }^{-1}\right)+25 \mathrm{~kg} \mathrm{ZnSO}_{4}$ as compared to $100 \%$ RDF (150-60-40 kg NPK $\mathrm{ha}^{-1}$ ) alone (Ashoka and Sunitha 2011).

\section{Soil health}

Paramasivan et al., (2011) noticed significantly higher available $\mathrm{N}$ in soil with application of $250 \mathrm{~N}+60 \mathrm{P}_{2} \mathrm{O}_{5}+25 \mathrm{~K}_{2} \mathrm{O}+10$ $\mathrm{kg} \mathrm{Zn} \mathrm{ha}{ }^{-1}$ but highest available $\mathrm{P}$ and $\mathrm{K}$ was 
observed with $200 \mathrm{~N}+70 \mathrm{P}_{2} \mathrm{O}_{5}+25 \mathrm{~K}_{2} \mathrm{O}+10$ $\mathrm{kg} \mathrm{Zn} \mathrm{ha}{ }^{-1}$ and $250 \quad \mathrm{~N}+60 \quad \mathrm{P}_{2} \mathrm{O}_{5}+31.25$ $\mathrm{K}_{2} \mathrm{O}+10 \mathrm{~kg} \mathrm{Zn} \mathrm{ha}^{-1}$, respectively.

It is concluded that judicious use of NPKSZn improved yield and quality of kharif fodder viz. maize, sorghum, bajra and teosinte. The optimized dose of these nutrients also depicted in enhancing the yield as well as advantageous to the growers. Efficient use of balanced nutrients either from chemical, organic or biofertilizers sources has been proven to be beneficial for baby corn production in terms of yield, nutritional value and net profitability in baby corn production.

\section{Future thrust of research}

- Rice-wheat, the most productive system extended over entire Indo-Gangetic plains (10.2 $\mathrm{m}$ ha) has reached at almost culminating point with regards to production under existing situation.

- Diversification accompanied with intensification is the effective tools to the further activate it on both productivity as well as economic fronts which are dire essential, since system is contributing significant quantum of food grain in the national pool.

- Cultivation of green gram/black after harvesting of wheat during summer is a recommended practice in rice-wheat but sowing of these crops beyond $10^{\text {th }}$ April has found non-remunerative.

- Under such specific condition, maize grown for baby corn production may prove promising and remunerative option for economic reforms of the farming community mostly in peri-urban areas.

- Baby corn is an extremely short duration fascinating cereal vegetable preferred in the elite group of society with advantage of planting round the year. Income and employment both can be enhanced through production of baby corn.
- Fertility management plays a key role in baby corn production and it exhibit full potential only when supplied with adequate quantities of nutrients at proper time. This is particularly important in achieving the higher yield of baby corn and green fodder as well as for maintaining the soil fertility.

- Hence, the long term evaluation of experimental results is pertinent for sustainability of baby corn production as pre- Kharif crop. Looking at the good response of the baby corn to secondary and micro-nutrients, a few more micronutrients may be tried in future.

\section{Acknowledgement}

The authors acknowledge esteemed referee for revision of manuscript whose comments and advice has greatly enhanced this article.

\section{References}

Abrol, V., Sankar, G.R.M., Singh, M. and Jaiswal, J.S. 2007. Optimization of fertilizer requirement of maize based on yield and rainfall variation from permanent manurial trials under dry-sub humid inceptisol. Indian. J. Dryland. Agric. Res. Dev., 22:15-21.

Abudulahi, H., Sarobil, E., Vichukit, K. and Suwan, N.C. 2006. Uptake and response of maize (Zea mays L.) varieties and nitrogen and phosphorus fertilizer in semi-arid of Eastern Ethiopia. Keset. J. Natu. Sci., 40: 604-615.

Abunyewa, A.A. and Quarshie, M. 2004. Response of maize to magnesium and zinc application in the semi-arid zone of West Africa. Asian J. Plant Sci., 3:1-5.

Adhikary, B.H. and Pandey, B.R. 2007. Response of sulphur on maize (Zea mays L.) production in acid soils of Rampur, Chitwan. J. Inst. Agric. Anim. Sci., 28: 4955.

Adiloglu, S. 2007. The effect of increasing nitrogen and zinc doses on iron, copper and manganese content of maize plant in calcareous and zinc deficient soils. Asian 
J. Plant Sci., 5: 504-507.

Adiloglu, S. and Saglam MJ. 2005. The effect of increasing nitrogen doses on zinc content of maize plant in soils of different properties. Pak J Bio Sci. 8: 905-909.

Ahlawat, I.P.S., Gangaiah, B. and Singh, O.P. 2005. Effect of fertilizers and stover management on productivity and soil fertility on chickpea (Cicer arietinum)maize (Zea mays) cropping system. Indian J. Agric Sci., 75: 400-403.

Ahmad, M., Hussain, N., Jan, N., Ahmad, K. and Hussain S. 2007. Response of maize to phosphorus levels and plant density. Sarhad J. Agric., 21: 69-73.

Alam, MM and Islam, M.N. 2003. Effect of sulphur and nitrogen on the yield and seed quality of maize (cv. Barnali). J. Bio. Sci., 3:643-654.

Amanullah, I. A. and Irfanullah Hidayat Z. 2016.Potassium management for improving growth and grain yield of maize (Zea mays L.) under moisture stress condition. Sci. Reports, 6: 34627. DOI: 10.1038/srep34627

Amin, M., Razzaq, A., Ullah, R. and Ramzan, M. 2006. Effect of planting methods, seed density and nitrogen-phosphorus (NP) fertilizer levels on sweet corn (Zea mays L.) J. Res. (Sci.), Bahauddin Zakariya Univ. Multan, Pakistan, 17: 83-89.

Arif, M., Amin, I., Jan, T.M., Iqbal, M., Khalid, N., Khan, N.U. and Marwat, B.K. 2010a. Effect of plant population and $\mathrm{N}$ levels and methods of application on ear characters and yield of maize. Pak. J. Bot., 42: 1959-1967.

Arif, M., Jan, M.T., Khan, N.U., Akbar, H., Khan, S.A., Khan, M.J., Khan, A., Munir, I., Saeed, M. and Iqbal, A. 2010b. Impact of plant population and nitrogen levels on maize. Pak. J. Bot., 42:3907-3913.

Arya, K.C. and Singh, S.N. 2000. Effect of different levels of phosphorus and zinc on yield and nutrients uptake of maize (Zea mays) with and without irrigation. Indian J. Agron., 45:717-721.

Ashoka, P., Anand, S.R., Mudalagiriyappa and Smitha, R. 2009. Effect of macro and micronutrients with organics on growth, quality, yield and economics of baby corn
(Zea mays L.) in Tungabhadra Command area. Crop Res., 37: 15-18.

Ashoka, P. and Sunitha, M.N.H. 2011. Effect of different nutrient management practices on yield, economics and nutrient uptake of baby corn (Zea mays L.). Res. Crops, 12:368-371.

Asif, M. and Amanullah, A.M. 2007. Phenology, leaf area and yield of spring maize cv. Azam as affected by levels and timing of potassium application. World Appl. Sci. J., 2: 299-303.

Ayub, M., Ahmad, R., Nadeem, M.A., Ahmad, B. and Khan, R.M.A. 2003. Effect of different levels of nitrogen and seed rates on growth, yield and quality of maize fodder. Pak. J. Agri. Sci., 40:140-142.

Azab, M.E.E. 2015. Increasing $\mathrm{Zn}$ ratio in a compound foliar NPK fertilizer in relation to growth, yield and quality of corn plant. J. Inno. Pharma Biol. Sci., 2:451:468.

Bakht, J., Ahmad, S., Tariq, M., Habib, A. and Shafi, M. 2006. Response of maize to planting methods and nitrogen fertilizer. J. Agric. Bio. Sci., 1: 8-14.

Banarjee, M., Singh, S.M. and Maiti, D. 2004. Effect of nitrogen and plant population on yield and quality of different popcorn varieties (Zea mays Everta). J. Interacad., 8:181-186.

Bharathi, C. and Poongothai, S. 2008. Direct and residual effect of sulphur on growth, nutrient uptake, yield and its use efficiency in maize and subsequent greengram. Res. J. Agric. Biol. Sci., 4:368-372.

Bindhani, A., Barik, K.C., Garnayak, F.M. and Mahapatra, P.L. 2007. Productivity and nitrogen use efficiency of baby corn (Zea mays L.) at different level and time of nitrogen application under rainfed condition. Indian J Agric Sci., 78: 629 631.

Bindhani, A., Barik, K.C., Garnayak, L.M. and Mahapatra, P.L. 2005. Nitrogen management in baby corn (Zea mays L.). Indian J. Agron., 52:135-138.

Carpici, E.B., Celik, N. and Bayram, G. 2010. Yield and quality of forage maize as influenced by plant density and nitrogen rate. Turk. J. Field Crops, 15:128-132. 
Chauhan, N. 2010. Effect of integrated nutrient management on growth, yield and economics of sweet corn (Zea mays L). J. Prog. Agric., 1:8-10.

Choudhary, P.M., Patil, H.E. and Hanikare, R.H. 2006. Effect of INM in maize (Zea mays L.) on pattern of leaf area and dry matter production. Intern. J. Plant Sci., 1:17-21.

Dadhich, L.K. and Gupta, A.K. 2005. Effect of sulphur, zinc and planting pattern on yield and quality of fodder pearl millet (Pennisetum glaucum). Indian J. Agric Sci., 75: 49-51.

Das, A., Patel, D.P., Munda, G.C. and Ghosh, P.K. 2010. Effect of organic and inorganic sources of nutrient on yield, nutrient uptake and soil fertility of maize (Zea mays)-mustard (Brassica compestris) cropping system. Indian $J$. Agric. Sci., 80: 85-88.

Das, S., Ghosh, G., Kaleem, M.D. and Bahadur, V. 2008. Effect of different levels of nitrogen and crop geometry on the growth, yield and quality of baby corn (Zea mays L.) CV. 'GOLDEN BABY'. ISHS Acta Horticulturae 809: International Symposium on the SocioEconomic Impact of Modern Vegetable Production Technology in Tropical Asia.

Dhananjaya, B.C. and Basavaraj, B. 2002. Effect of sulphur application on sulphur fraction in soil as influenced by maize rhizosphere. Karnataka J. Agric. Sci., 15:148-150.

Dibaba, D.H., Hunshal, C.S., Hiremath, S.M., Awaknavar, J.S., Wali, M.C., Nadagoudabt and Chandrashekar, C.P. 2014. Growth and yield of maize (Zea mays L.) hybrids as influenced by application of N, P, K and S levels. Karnataka J. Agric. Sci., 27: 454-459.

Dixit SP. 2006. Effect of lime and phosphorus on yield and nutrient uptake by maize in mountain acidic soil of Himachal Pradesh. Ann. Agric. Res. 27: 277-282.

Dwivedi, S.K., Singh, R.S. and Dwivedi, K.N. 2002. Effect of sulphur and zinc nutrition on yield and quality of maize in typic Ustochrept soil of Kanpur. J. Indian Soc. Soil Sci., 50: 70-74.

Effa, E.B., Uwah, F.D. and Ukeh, A.D. 2011.
Yield response of popcorn (Zea mays L. var. everta) to nitrogen and lime amendment in a south eastern rainforest environment of Nigeria. Ame. J. Plant Physiol., 6: 304-311.

Gangaiah, B. and Ahlawat, I.P.S. 2008. Response of chickpea (Cicer arietinum) to seeding time and phosphorus and their after effect on succeeding baby corn (Zea mays L.). Indian J. Agron., 53:42-46.

Ghodpage, R.M., Balpanda, S.S., Babhulka, V.P. and Pongade, S. 2008. Effect of phosphorus and zinc fertilization on nutrient content in root, yield and nutritional quality of maize. J. Soils Crop., 18: 458-461.

Gul, S., Khan, M.H., Khanday, B.A. and Nabi, S. 2015. Effect of sowing methods and NPK levels on growth and yield of rainfed maize (Zea mays L.). Scientifica, 2015: 16.

Hani, A.E., Hamad, M.A. and Eltom, EA. 2006. The effect of nitrogen and phosphorus fertilization on growth, yield and quality of forage maize (Zea mays L.). Agron. J., 5: 515-518.

Haque, M.M., Hamid, A. and Bhuiyan, N.I. 2001. Nutrient uptake and productivity as affected by nitrogen and potassium application levels $\mathrm{N}$ maize/sweet potato intercropping system. Korean J. Crop Sci., 46: 1-5.

Harikrishna, B.L., Dasog, G.S. and Patil, P.L. 2005. Effect of soil depth, $\mathrm{N}$ doses and its split application on maize plant height, LAI and dry matter yield at different growth stages. Karnataka J. Agric. Sci., 18:364-369.

Hussain, N., Khan, A.Z., Akbar, H., Bangash, N.G., Hayat, Z. and Haress, M. 2007. Response of maize varieties to phosphorus and potassium levels. Sarhad J. Agric., 23: 881-887.

Hussaini, M.A., Ogunlela, V.B., Ramalan, A.A. and Falaki, A.M. 2001. Growth and development of maize (Zea mays L.) in response to different levels of nitrogen, phosphorus and irrigation. Crop Res., 22: 141-149.

Jain, N.K. and Dahama, A.K. 2005. Residual effect of phosphorus and zinc on yield, 
nutrient content and uptake and economic of pearlmillet (Pennisetum glaucum)wheat (Triticum aestivum) cropping system. Indian J. Agric. Sci., 75: 281-284.

Jakhar, S.R., Singh, M. and Balai C.M. 2006. Effect of farm yard manure, phosphorus and zinc level on growth, yield and quality and economics of pearlmillet (Pennisetum glaucum). Indian J. Agric. Sci., 6:58-61.

Jaliya, M.M., Chiezey, U.F., Tanimu, B., Othman, M.K., Babaji, B.A., Sani, B.M. and Mani, H. 2012. Effects of Nitrogen and sulfur fertilizers on nitrogen content in soil, ear leaf, flag leaf and grain of QPM maize varieties at Samaru Zaria. J. Agric. Sci., 4: 217-222.

Jan, A., Aslam, I.K., Akber, H. and Khan, G.D. 2007. Yield potential of maize hybrid under intensive input management. Sarhad J. Agric., 23: 31-34.

Jeet, S., Singh, J.P. and Kumar, R. 2016. Production potential and nutrient uptake of quality protein maize hybrid as influenced by nitrogen and sulphur fertilization. J. Agri-Search, Accepted.

Jeet, S. 2012. Effect of nitrogen and sulphur levels on growth and yield of quality protein maize (Zea mays L.) hybrids under dryland condition. Agronomy, Ph.D. Thesis submitted at BHU, Varanasi.

Jeet, S., Singh, J.P., Kumar, R. and Om, H. 2014. Response of nitrogen and sulphur levels on productivity and profitability of QPM hybrid (Zea mays) under dryland condition of Eastern Uttar Pradesh. Indian J, Agric, Sci., 84: 589-594.

Jeet S, Singh JP, Kumar R, Prasad RK, Kumar P, Kumari A, Prakash P. 2012. Effect of nitrogen and sulphur levels on yield, economic and quality of QPM hybrid under dryland condition of Eastern Uttar Pradesh, India. Journal Agric Sci. 4: 3138.

Jena, N., Vani, K.P., Rao, V.P. and Sankar, A.S. 2015. Effect of nitrogen and phosphorus fertilizers on growth and yield of quality protein maize (QPM). Intern. J. Sci. Res., 4:1839-1840.

Kadir, A.I.S.M., Sharanappa and Reddy, P.J. 2002. Effect of composts and fertilizer levels on structure of growth and yield in maize (Zea mays L.). Madras Agric. J., 89: 720-723.

Kakar, K.N., Kakar, R.G., Rehman, S.V., Rehman, F. and Haq, I.U. 2006. Zinc application and plant population effects on yield and yield component of maize. Indian J. Plant Sci., 5:715-721.

Kalpana, R. and Krishnarajan, J. 2002. Effect of dose and time of potassium application on yield and quality of baby corn. Agric. Sci. Digest, 22:59-60.

Karki, T.B., Kumar, A. and Gautam, R.C. 2005. Influence of INM on growth, yield, content and uptake of nutrient and soil fertility status in maize (Zea mays L.). Indian J. Agric. Sci., 75: 682-685.

Kataraki, N.G., Desai, B.K., Pujari, B.J. 2004. Integrated nutrient maize irrigated maize. Karnataka J. Agric. Sci., 17 : 1-4.

Keskin, B., Akdeniz, H., Yilmaz, I.H. and Turan, N. 2005. Yield and quality of forage corn (Zea mays L.) as influenced by cultivars and nitrogen rate. J. Agron., 4:38-141.

Khan, A.M., Abid, M., Hussain, N. and Masood MU. 2005. Effect of phosphorus levels on growth and yield of maize (Zea mays L.) cultivars under saline conditions. Intern. J. Agric. Biol., 7:511-514.

Khan, M.J., Khan, M.H., Khattak, R.A. and Jan, M.J. 2006. Reponses of maize to different levels of sulphur. Comm. Soil Sci. Plant Anal., 97: 41 -51.

Khan, Z.H., Shahid, I., Iqbal, A., Akbar, N. and Jones, L.D. 2011. Response of maize (Zea mays L.) varieties to different levels of nitrogen. Crop Environ., 2:15-19.

Kumar, R., Bohra, J.S., Singh, A.K. and Kumawat, N. 2015. Productivity, profitability and nutrient-use efficiency of baby corn (Zea mays) as influenced of varying fertility levels. Indian J. Agron., 60:285-290.

Kumar, R. 2013. Effect of NPKS and Zn application on growth, yield and quality of pre-kharif baby corn (Zea mays L.).Thesis submitted to the Department of Agronomy, Institutes of Agricultural Sciences, Banaras Hindu University, Varanasi, Uttar Pradesh-221 005, India.

Kumar, A. 2009. Influence of varying plant 
population and nitrogen levels on growth, yield, economics and nitrogen use efficiency of popcorn (Zea mays Everta). Crop Res., 37:19-23.

Kumar, A., Chhillar, R.K. and Gautam, R.C. 2006. Nutrient requirement of winter maize (Zea mays L.) based intercropping system. Indian J. Agric. Sci., 76: 315-318.

Kumar, A. and Dhar, S., 2010. Evaluation of organic and inorganic sources of nutrient in maize (Zea mays) and their residual effect of wheat (Triticum aestivum) under different fertility levels. Indian J. Agric. Sci., 80:364-371.

Kumar, M.A.A., Gali, S.K. and Patil, R.V. 2007. Effect of levels of NPK on quality of sweet corn growth on vertisol. Karnataka J. Agric. Sci., 20:44-46.

Kumar, R. and Bohra, J.S. 2014. Effect of NPKS and $\mathrm{Zn}$ application on growth, yield, economics and quality of baby corn. Archive Agron. Soil Sci., 60:1193-1206.

Kumar, R., Bohra, J.S., Kumawat, N., Kumar, A., Kumari, A. and Singh, A.K. 2015. Root growth, productivity and profitability of baby corn (Zea mays L.) as influenced by nutrition levels under irrigated ecosystem. Res. Crops 17:41-46.

Kumar, R., Bohra, J.S., Kumawat, N. and Singh, A.K. 2015. Fodder yield, nutrient uptake and quality of baby corn (Zea mays L.) as influenced by NPKS and Zn fertilization. Res. Crops, 16:243-24, DOI: 10.5958/2348-7542.2015.00036.4.

Kunjir, S.S., Pinjari, S.S., Suryavanshi, J.S. and Bhonde, T.S. 2009. Effect of planting geometry, nitrogen levels and micronutrients on growth and yield of Sweet corn. Bioinfolet, 6: 22-24.

Latha, M.R., Savithri, P., Indirani, R. and Kamraj, S. 2002. Residual effect of zinc enriched organic manures on availability of micro nutrients in maize-sunflower cropping system. Madras Agric. J., 89:120-121.

Leary, O.M.J. and Rehm, G.W. 1990. Nitrogen and sulfur effects on the yield and quality of corn grown for grain and silage. $J$. Prod. Agric., 3:135-140.

Leite, U.T., Aquino, B.D., Rocha, R.N.C. and Silva, J. 2003. Leaf boron, copper, manganese and zinc critical levels in maize. Bio Sci. J., 19:115-125.

Liu, H., Gan, W., Rengel, Z. and Zhao, P. 2016. Effects of zinc fertilizer rate and application method on photosynthetic characteristics and grain yield of summer maize. J. Soil Sci. Plant Nutri., 16: 550562.

Lone, A.A., Allai, B.A. and Nehvi, F.A. 2013. Growth, yield and economics of baby corn (Zea mays L.) as influenced by integrated nutrient management (INM) practices. African J. Agric. Res., 45374540.

Luikham, E., Rajan, K.J., Rajendran, K. and Mariam, P.S. 2003. Effect of organic and inorganic nitrogen on growth and yield of baby corn (Zea mays L.). Agric. Sci. Digest, 23:119-121.

Mahdi, S.S., Hasan, B. and Singh, L. 2012. Influence of seed rate, nitrogen and zinc on fodder maize (Zea mays L.) in temperate conditions of western Himalayas. Indian J. Agron., 57:85-88.

Majumdar, B., Venkatesh, M.S., Kumar, K. and Patiram. 2002. Effect of nitrogen, sulphur and pig manure application on yield, nutrient uptake and quality parameters of maize-mustard crop rotation and residual nutrient buildup in an acidic alfisols of Meghalaya. J. Hill Res., 15:63-70.

Marschner, H. 1995. Mineral Nutrition of higher plants Academic Press, Harcourt Brad. Joranvaic Publishers, London.

Masood, M., Shamsi, I.H., Hussai, N. and Shah, W.A. 2003. Performance of maize varieties as affected by different NP levels. Asian J. Plant Sci., 2:535-538.

Maurya, K.L., Sharma, H.P., Tripathi, H.P. and Singh, S. 2004. Effect of fertility levels of nitrogen and sulphur on growth, yield and quality of winter maize. Haryana $J$. Agron., 20:80-81.

Maurya, K.L., Sharma, H.P., Tripathi, H.P. and Singh, S. 2005. Effect of nitrogen and sulphur application on yield attributes, yield and net returns of winter maize (Zea mays L.). Haryana J. Agron., 21:115-116.

Meena, O., Khafi, H.R., Shekh, M.A., Mehta, A.C. and Davda BK. 2007a. Effect of vermicompost and nitrogen on content and yield of rabi maize. Crop Res., 33: 
53-54.

Meena, O., Khafi, H.R., Shekh, M.A., Mehta, A.C. and Davda, B.K. 2007b. Response of rabi maize (Zea mays L.) to vermicompost and nitrogen levels. Res. Crop, 8: 93-94.

Meena, S.K., Mundra, S.L. and Singh, P. 2013. Response of maize (Zea mays) to nitrogen and zinc fertilization. Indian J. Agron., 58: 127-128.

Mehta, S., Bedi, S. and Vashist, K.R. 2011. Performance of winter maize (Zea mays) hybrid to planting methods and nitrogen levels. Indian J. Agric. Sci., 81:50-54.

Mehta, Y.K., Shaktawat, M.S. and Singh, S.M. 2005. Influence of sulphur, phosphorus and farmyard manure on yield attributes and yield of maize (Zea mays) in southern Rajasthan conditions. Indian J. Agron., 50: 203-205.

Mishra, B.N., Yadav, R.S., Rajput, A.L. and Pandey, M. 2009. Effect of plant geometry and nitrogen application on yield and quality of winter maize (Zea mays L.). Indian J. Agron., 39:468-469.

Mohsin, A.U., Ahmad, A.U.H., Farooq, M. and Ullah, S. 2014. Influence of zinc application through seed treatment and foliar spray on growth, productivity and grain quality of hybrid maize. The J. Ani. Plant Sci., 24:1494-1503.

Muthukumar, V.B., Velayudharm, K. and Thavaprakash, N. 2005. Effect of plant growth regulators and time of nitrogen application on quality and green cob yield of baby corn (Zea mays L.). Madras Agric. J., 92: 545-548.

Nanjudappa, G., Manure, G.R. and Badiger, M.K. 1994. Yield and uptake of fodder maize (Zea mays) as influenced by nitrogen and potassium. Indian J. Agron., 39:473-477.

Nazakat, N., Sarwar, G., Naseeb, T. and Yousuf, M. 2004. Effect of various levels of $\mathrm{N}$ and $\mathrm{P}$ on the growth and yield of maize. Sarhad J. Agric., 20: 251-253.

Neupane, M.P., Singh, R.K., Kumar, R. and Kumari A. 2011. Quality and yield performance of baby corn (Zea mays L.) as influenced by nitrogen sources and row spacing. Environ. Ecol., 29:1215-1218.

Neupane, M.P., Singh, R.K., Kumar, R. and
Kumari, A. 2012. Response of baby corn (Zea mays L.) to nitrogen sources and row spacing. Environ. Ecol., 29:1176-1179.

Oktem, A.G. and Oktem, A. 2005. Effect of nitrogen and inter row spaces on sweet corn (Zea mayssacharata Sturt) ear characters. Asian J. Plant Sci., 4: 361364.

Onasanya, R.O., Aiyelari, O.P., Oikeh, S., Nwilene, F.E. and Oyelakin, O.O. 2009. Growth and yield response maize to different rates of nitrogen and phosphorus fertilization Southern Nigeria. World J. Agric. Sci., 5:400-407.

Pandey, A.K., Prakash, V., Mani, V.P. and Singh, R.D. 2000. Effect of rate of nitrogen and time of application on yield and economics of baby corn (Zea mays). Indian J. Agron., 45:338-343.

Panwar, A.S. and Munda, G.C. 2006. Response of baby corn (Zea mays L.) to nitrogen and land configuration in mid hills of Meghalaya. Indian J. Agric. Sci., 76:293296.

Paramasivan, M., Kumaresan, K.R., Malarvizhi, P., Mahimairaja, S. and Velayudham, K. 2010. Effect of different levels of NPK and $\mathrm{Zn}$ on yield and nutrient uptake of hybrid maize (COHM 5) in Mayamankuruchi (Myk) series of soil of Tamil Nadu. Asian J. Soil Sci., 5:157-161.

Paramasivan, M., Kumarsesan, K.R. and Malarvizhi, P. 2011. Effect of balanced nutrition on yield, nutrient uptake and soil fertility of maize (Zea mays) in vertisol of Tamil Nadu. Indian J. Agron., 56:133137.

Parasuraman, P. 2005. Studies on integrated nutrient management of hybrid maize (Zea mays L.) under irrigated condition. Madras Agric. J., 92: 89-94.

Patel, P.C., Yadavendra, J.P. and Kotecha, A.V. 2004. Effect of source and level of sulphur on seed yield and nitrogen and sulphur uptake by lurcern (Medicago sativa). Indian J. Agron., 49: 128-130.

Rajendran, K. and Singh, S.D. 1999. Effect of irrigation and nitrogen levels on yield, water requirement, water use efficiency and quality of baby corn (Zea mays L.). Agric. Sci. Digest, 19:159-161. 
Ram, V., Singh, R.N. and Singh, K. 2006. Studies on integrated use of FYM, nitrogen and sulphur on growth, yield attributes and yield on winter maize (Zea mays L.). Plant Archi., 6:749-752.

Rao, L.K., Kumar, R.A. and Lal, G.M. 2009. Effect of integrated nitrogen management on growth and yield of baby corn (Zea mays L.) cv. Mridula. J. Maharashtra Agric. Univ., 34:249-251.

Rasheed, M., Ali, H. and Mohmood T. 2004. Impact of nitrogen and sulphur application of growth and yield of maize (Zea mays L.) crop. J. Res. Sci., 15:153157.

Rasheed, M., Khalid, J. and Hussain, A. 2004. Biological response of maize to variable grades of phosphorus and planting geometry. Intern. J. Agric. Biol., 3:462464.

Raskar, S.S., Sonani, V.V. and Shelke, A.V. 2012. Effects of different levels of nitrogen, phosphorus and zinc on yield and yield attributes of maize (Zea mays L.). Adv. J. Crop Imp., 3:126-128.

Rasool, S., Kanth, R.H., Hamid, S., Raja, W., Alie, B.A. and Dar ZA. 2015. Influence of integrated nutrient management on growth and yield of sweet corn (Zea mays L. saccharata) under temperate conditions of Kashmir valley. Ame. J. Exp. Agric., 7:315-325.

Sadiq, S.A., Jan, A., Nooruddin, S., Kakar, K.N. and Wahid, N.A. 2005. Effect of graded application of potash on maize darn at different fertility levels. Indian J. Plant Sci., 4: 585-590.

Saha, M. and Mondal, S.S. 2006. Influence of integrated plant nutrient supply on growth, productivity and quality of baby corn (Zea mays) in Indo-Gangetic Plains. Indian J. Agron., 51: 202-205.

Sahoo, S.C. and Panda, M.M. 2001. Effect of phosphorus and detasseling on yield of baby corn. Indian J. Agric. Sci., 71: 2122.

Sahoo, S.C. 2011. Yield and economic of baby corn (Zea mays L.) as affected by varieties and levels of nitrogen. Range Mgt Agrofo., 32: 135-137.

Sahoo, S.C. and Panda, M.M. 1997. Fertilizer requirement of baby corn (Zea mays L.) in wet and winter season. Indian J. Agric. Sci., 64: 397-398.

Sahoo, S.C. and Panda, M.M. 1999. Fertilizer requirement of baby corn in wet and winter seasons. Indian J. Agric. Sci., 67: 397-398.

Sakal, R., Sinha, R.B., Singh, A.P., Bhogal, N.S. and Ismail, M.D. 2000. Influence of sulphur on yield and mineral nutrition of crops in maize-wheat sequence. J. Indian Soc. Soil Sci., 48:325-329.

Sankaran, N., Meena, S. and Sakthivel, N. 2005. Input management in maize. Madras Agric. J., 92: 464-468.

Sankaran, S., Savithri, P., Poongopathai, S. and Sakthikumaran, S. 2002. Direct and residual effect of sulphur application on maize-greengram cropping system. Fert. Mark. News, 33:1-8.

Sarwar, M. 1993. Effect of different levels of N fertilizers on the yield and quality of maize. Pak. J. Agri. Sci., 30: 99-101.

Sarwar, M., Jilani, G. and Rafique, E. 2012. Impact of INM on yield and nutrient uptake by maize under rainfed condition. Pak. J. Nutri., 11: 27-33.

Sekar, S., Amanullah, M.M., Manoharan, S., Muthukrishnan, P., Subramanian, K.S. and Vincent, S. 2010. Influence of fertilizer levels and growth substances on yield and economics of hybrid maize. Madras Agric J., 97: 58-61.

Sekar, S., Amanullah, M.M., Manoharan, S. and Subramanian, K.S. 2012. Influence of fertilizers levels and growth substances on hybrid maize under irrigated condition. Agric. Sci. Digest., 32:79-82.

Shanmugasundaram, R and Savitri, P. 2005. Effect of levels and frequency of zinc sulphate application on yield and EDTA$\mathrm{Zn}$ availability in maize-safflower cropping system. Madras Agric. J. 92: 252-257.

Shanti, K.V.P., Rao, M.R., Reddy, M.S. and Sarma R.S. 1997. Response of maize (Zea mays) hybrid and composite to different levels of nitrogen. Indian J. Agric. Sci., 67:424-425.

Sharifi, R.S. and Taghizadeh, R. 2009. Response of maize (Zea mays L.) cultivar to 
different levels of nitrogen fertilizer. $J$. Food Agric. Environ., 7: 518-521.

Sharma, J.J. and Thakur, D.R. 1995. Effect of nitrogen and time of split application on growth and yield of rainfed maize (Zea mays L.). Himachal J. Agric. Res., 21:1-4.

Shivran, R.K., Kumar, R. and Kumari, A. 2013. Influence of sulphur, phosphorus and farm yard manure on yield attributes and productivity of maize (Zea mays L.) in humid south eastern plains of Rajasthan. Agric. Sci. Digest, 33:9-14.

Siam, H.S., Kader, E.M.G.A. and Alia, E.H.I. 2008. Yield and yield component of maize as affected by different sources and application rates of $\mathrm{N}$ fertilizers. Res. J. Agric. Biol. Sci., 4:399-412.

Singh, D. and Choudhary, J. 2008. Effect of plant population and fertilizer levels on yield and economics of popcorn (Zea mays var. indurata). Indian J. Agric. Sci., 78:370374.

Singh, D. and Nepalia, V. 2009. Influence of integrated nutrient management on quality protein maize (Zea mays L.) on productivity and soils of Southern Rajasthan. Indian J. Agric. Sci. 79:10201022.

Singh, D. and Singh, S.M. 2006. Response of early maturing maize (Zea mays L.) hybrid to applied nutrient and plant densities under agro-climatic condition of Udaipur in Rajasthan. Indian J. Agric. Sci., 76:372-374.

Singh, G., Singh, N. and Kaur, R. 2016a. Effect of integrated nutrient management on yield and quality parameters of baby corn (Zea mays L.). Intern J. Appl. Pure Sci. Agri., 2:161-166.

Singh, G., Singh, N. and Kaur, R. 2016b. Integrated nutrient management for increasing growth with sustainability of baby corn. Intern. J. Bioas., 5:4817-4820.

Singh, M.K., Singh, R.N., Singh, S.P., Yadav, M.K. and Singh, V.K. 2010. INM for higher yield, quality and profitability of baby corn (Zea mays). Indian J. Agron., 55:100-104.

Singh, U., Saad, A.A., Ram, T., Chand, Lekh M.S.A. and Aga, A.A. 2012. Productivity, economics and nitrogen-use efficiency of sweet corn (Zea mays saccharata) as influenced by planting geometry and nitrogen fertilization. Indian J. Agron., 57:43-48.

Sinha, R.B., Sakal, R. and Kumar, S. 1995. Sulphur and phosphorus nutrition of winter maize in calcareous soil. J. Indian Soc. Soil Sci., 43:413-418.

Sobhana, V., Kumar, A., Idnani, L.K., Singh, I., Shivadhar. 2012. Plant population and nutrient requirement for baby corn hybrids (Zea mays). Indian J. Agron., 57:294-296.

Sofi, K.A., Chesti, M.H., Baba, Z.A. and Lene, B.A. 2005. Growth and yield of maize (Zea mays) as influenced by application of nitrogen and potassium. Environ. Ecol., 23: 586-588.

Sofi, K.A., Sharma, D. and Thomas, T. 2004. Effect of nitrogen and potassium nutrition on yield, nutrient uptake and soil fertility of maize (Zea mays L.) under rainfed condition of Uttar Pradesh. Environ. Ecol., 22 :483-485.

Sridhar, V. 1988. Effect of fertility levels on Rabi maize under different moisture regimes based on IW/CPE ratio. Ph.D. Thesis, Dept. of Agronomy, B.H.U., Varanasi.

Srikant, M., Amanullah, M.M. and Muthukrishnan P. 2009. Influence of plant density and fertilizer on yield attributes yield and grain quality of hybrid maize. Madras Agric. J., 96:139-143.

Srinivasarao, C., Ali, M., Venkateswarlu, S., Rupa, T.R., Singh, K.K., Kundu, S. and Prasad, J.V.N.S. 2010. Direct residual effects of integrated sulphur fertilization in maize (Zea mays)-chickpea (Cicer arietinum) cropping system on Typic Ustochrept. Indian J. Agron., 55:259-263.

Sujatha, M.G., Lingaraju, B.S., Palled, Y.B. and Ashalatha, V. 2008. Importance of integrated nutrient management practices in maize under rainfed condition. Karnataka J. Agric. Sci., 21 (3): 334-338.

Thakur, D.R., Om, P., Kharwara, P.C. and Bhalla, S.K. 1997. Effect of nitrogen and plant spacing on growth, development and yield of baby corn. Indian J. Agron., 42:479483.

Thakur, D.R., Om, P., Kharwara, P.C. and Bhalla, 
S.K. 1998. Effect of nitrogen and plant spacing on yield, nitrogen uptake and economics in baby corn (Zea mays L.). Indian J. Agron., 43:688-671.

Thakur, D.R. and Sharma, V. 1999. Effect of varying rates of nitrogen and its schedule of application in baby corn (Zea mays L.). Indian J. Agric. Sci., 69:93-95.

Thavaprakaash, N., Velayudham, K. and Muthukumar, V.B. 2005.Effect of crop geometry, intercropping system and integrated nutrient management practices on productivity of baby corn (Zea mays L.) based intercropping systems. Res. J. Agric. Biol. Sci., 1:295-302.

Venkatesh, M.S., Majumdar, B., Kumar. K. and Patiram. 2002. Effect of phosphorus and lime on yield and $\mathrm{P}$ uptake by maize and forms of soil acidity in Typic hapludalf of Meghalaya. J. Indian Soc. Soil Sci., 50 :254-258.

Verma, N.K. 2011. INM in winter maize (Zea mays L.) sown at different dates. J. Plant Bree. Crop Sci., 3:161-167.

Verma, N.K., Pandey, B.K., Singh, U.P. and Lodhi, M.D. 2012. Effect of sowing dates in relation to integrated nitrogen management on growth, yield and quality of rabi maize. The J. Ani. Plant Sci., 22:324-329.

Vishalu, L., Nagaraju, H.V., Najappa, K.N., Kalyanamutrthy, D.N. and Kalaraju, N.
2009. Performance of hybrid maize to plant density and fertilizer levels under rainfed conditions. Crop Res., 37: 49-51.

Wang, Z. 2009. Effect of different schedules of baby corn (Zea Mays L.) harvests on baby corn yield, grain yield, and economic profit value. Masters Theses \& Specialist Projects. Paper 131.http://digitalcommons.wku.edu/theses $/ 131$

Wasaya, A., Tahir, M., Manaf, A., Ahmad, M., Shuaib, K. and Ahmad, I. 2011. Improving maize productivity through tillage and nitrogen management. African J. Bioctech., 10:19025-19034.

Xie, Z.Y., Wang, P., Hangfang, Z., Lixia, S., Ming, L. and Minghang, D. 2006. Effect of nitrogen types and application rate on source-sink relationship in summer maize on north China plain. Plant Nutri. Fert. Sci., 12: 294-300.

Yakadri, M., Kanta, T., Kumar, R. and Vijay, B. 2001. Effect of nitrogen and phosphorus on grain yield of hybrid maize (Zea mays L.). Agric. Sci, Digest, 21: 194 -195.

Zende, N.B., Pinjari, S.S., Suryawanshi, J.S. and Bhonde, T.S. 2009. Effect of nutrient management on growth, yield and quality, economics and nutrient partitioning of sweet corn. Bioinfolet, 6:16-21.

\section{How to cite this article:}

Rakesh Kumar, Narendra Kumawat, Sudhir Kumar, Amitesh Kumar Singh and Bohra, J.S. 2017. Effect of NPKS and Zn Fertilization on, Growth, Yield and Quality of Baby Corn-A Review. Int.J.Curr.Microbiol.App.Sci. 6(3): 1392-1428. doi: https://doi.org/10.20546/ijcmas.2017.603.161 